\title{
Knowledge about bacterial and viral pathogens present in wild mammals in Chile: a systematic review
}

\author{
Sebastián Llanos-Soto ${ }^{1}$ and Daniel González-Acuña²
}

\section{Knowledge about viral and bacterial pathogens present in wild mammals in Chile: a systematic review}

This study organizes all available information about viral and bacterial pathogens of wild mammals in Chile. This was done in order to identify pathogens that have been well-documented and recognize those that have not been properly studied, determine the number of articles that have been published annually about this topic and identify regions in Chile that concentrate the highest and lowest number of studies concerning viral and bacterial pathogens. A total of 67 scientific articles published in peer-reviewed journals from 1951 to 2018 were selected for revision. Results indicate that the number of publications has increased per decade but there are years in which no articles were published. Most studies addressed Leptospira, rabies, hantavirus, Mycobacterium avium paratuberculosis (MAP) and distemper. Rodentia, Carnivora, Chiroptera and Cetartiodactyla were the most studied mammal orders. Information about presence/absence of pathogens was found for 44 wild mammal species. Research was mainly carried out in central and southern Chile and the most commonly employed methods for pathogen diagnosis were serology and molecular techniques. Overall, research in wild mammals has been directed towards the evaluation of zoonotic diseases, while vector-borne and non-zoonotic diseases have been mostly neglected by the scientific community over the years.

Keywords: Bacteria; Chile; mammals; virus; zoonoses.

Palabras clave: Bacteria; Chile; mamíferos; virus; zoonosis.

\section{Introduction}

$\mathrm{K}$ nowledge about the presence of infectious diseases in wildlife is pivotal to understand the potential consequences that they might have on species conservation and their threat to human health ${ }^{1}$. Anthropogenic factors, such as the introduction of alien species, climate change, habitat loss and fragmentation and human encroachment in natural areas might increase the risk of disease transmission from wild reservoirs to domestic animals and humans ${ }^{2,3}$.

Diseases that are transmitted between animals and humans are called zoonoses and cause both economical and social losses, especially in underdeveloped and developing countries ${ }^{3}$. Zoonotic pathogens, such as rabies and hantavirus, have their origin in mammal reservoirs and are considered extremely important for public health systems because of their consequences on human health ${ }^{4,5}$. In this context, affected individuals may have their health compromised by zoonotic diseases, and in many cases, they might be wrongly characterized as common infections or even go unnoticed to health care institutions ${ }^{6}$. Urbanization and industrial activities, such as agriculture and forestry, have intensified in Chile during recent years and they will probably continue to do so in the future ${ }^{7}$. These factors may lead to habitat fragmentation, ecosystem disruption and over-exploitation of species, which added to the expansion of human and domestic animal populations in areas close to natural habitats, might contribute to the transmission of infectious diseases from free-living wild animals to domestic animals and humans ${ }^{8-11}$.

The objectives of this review were to (1) gather and organize all the information available in articles published in peer-reviewed journals involving the assessment of viral and bacterial infections in Chilean wild mammals, (2) identify which pathogens have been prioritized by the local scientific community and which have received little to no attention, (3) evaluate the number of articles published annually about the prevalence of viral and bacterial pathogens in wild mammal hosts and (4) recognize the number of studies developed in this topic in the different regions of Chile.

\section{Materials and Methods}

Peer-reviewed scientific publications evaluating the prevalence of viral and bacterial pathogens in Chilean wild
'Laboratorio de Enfermedades y Parásitos de Fauna Silvestre. Departamento de Ciencia Animal. Facultad de Ciencias Veterinarias, Universidad de Concepción, Chile. 2Laboratorio de Vida Silvestre. Departamento de Ciencia Animal. Facultad de Ciencias Veterinarias, Universidad de Concepción, Chile.

Conflicts of interest. None declared.

Submitted: June 10, 2018 Accepted: October 25, 2018

A Spanish version of this review was published in Rev Chilena Infectol, 2019; 36 February (1).

Corresponding author: Daniel González Acuña Facultad de Ciencias Veterinarias Universidad de Concepción Av. Vicente Méndez 595 Chillán, Chile.

Phone: +56 422208739 Fax: +56422208739 danigonz@udec.cl 
mammals were searched and listed following the Preferred Reporting Items for Systematic Reviews and Meta-Analyses (PRISMA) declaration guidelines ${ }^{12}$. Articles published in Spanish or English from January 1950 through July 2018 were selected for revision. Data from unpublished literature (grey literature) was excluded from this study (i.e., abstracts, books, local bulletins and presentations at scientific conferences) based on the fact that these types of scientific documents do not often undergo a rigorous peer-review process prior to publication. This means that the accuracy, reliability and quality of the findings being presented in these documents cannot be ensured. Viral and bacterial agents were considered pathogenic when there was information available in the literature indicating their ability to cause disease in animals, humans or both. The revision considered pathogens present in free-living native and introduced mammalian species, with the exception of domestic animals and individuals maintained in captivity in zoos, farms and exhibition centers. Publications about pathogens found in mammals from the Chilean Antarctic Territory were also excluded from the review, as they have been already reviewed in another scientific article ${ }^{13}$.

Google Scholar (https://scholar.google.cl/), Scielo Scientific Library (http://www.scielo.cl/) and PubMed (https://www.ncbi.nlm.nih.gov/pubmed/) databases were used to conduct an extensive search for publications. Keywords "bacteria", "bacterial", "Brucella", "coronavirus", “Corynebacterium", "distemper", "hantavirus”, "herpesvirus", "infectious disease", "Leptospira", "Mycobacterium", "Mycoplasma”, "parvovirus”, "pathogen”, "picornavirus", "rabies", "retrovirus", "Salmonella", "vector-borne", "viral", "virus", "zoonosis" AND "Carnivora", "Cetartiodactyla", "Chiroptera", "Didelphimorphia", "Lagomorpha", "mammal”, "Microbiotheria", "Paucituberculata", "Rodentia", "wildlife", "Xenarthra" AND "Chile" were inputed in independent searches. These same keywords were also employed to perform searches in Spanish to account for publications in local journals. Articles that were not available for download online were physically searched in the libraries from Universidad de Chile, Universidad Austral, Pontificia Universidad Católica de Chile and Universidad de Concepción. Information about prevalence for each pathogen was organized and listed in a supplementary table using Microsoft ${ }^{\circledR}$ Excel 2010. The table included data about mammal host, pathogen characterization (e.g., serotype, genetic lineage, class), region in Chile where the study was developed and technique used for diagnosis. Data from selected publications was analyzed using line graphs to evaluate a potential trend in the number of articles published per decade since 1951 and identify the most studied mammal orders in Chile.

Data was searched for a total of 150 mammal species from eight orders: Didelphimorphia (2), Paucituberculata
(1), Microbiotheria (1), Chiroptera (11), Xenarthra (3), Rodentia (63), Cetartiodactyla (47), Lagomorpha (2) and Carnivora (20). Three species were excluded from the review because their distribution was restricted to Antarctica (Ommatophoca rossii) or their presence in Chile has yet to be confirmed (Stenella attenuate and Stenella longirostris). Research studies that included previously diagnosed cases of viral and bacterial infections in their analysis (e.g., positive cases of rabies diagnosed by the Chilean National Institute of Public Health, ISP in Spanish) were also included in this review. Pathogens were listed from highest to lowest in the discussion depending on the number of articles available in the literature related to that specific pathogen.

\section{Results}

A total of 67 publications about viral and bacterial pathogens in Chilean mammals were included in this review. From the literature assessed, 34 studies evaluated the prevalence of viral pathogens and 35 studies concerned bacteria. Information about presence/absence of pathogens was found for 44 species from the Rodentia (15), Carnivora (10), Chiroptera (9), Cetartiodactyla (8), Didelphimorphia (1) and Lagomorpha (1) orders (Figure 1). Details about the results of this review are indicated in the Supplementary Table 1.

Overall, the number of studies addressing the infection or exposure to viral or bacterial pathogens in wild mammals has increased per decade (Figure 2), however, during the last decade there are years in which the number of articles published ranges from 0 to 2 (i.e., 2010, 2012 and 2016). Publications dedicated to each pathogen varied in number, most studies were related to Leptospira (16 studies), rabies virus (12 studies), hantavirus (10 studies), Mycobacterium avium paratuberculosis (8 studies) and canine distemper virus (6 studies).

The first study to record the presence of pathogens in wild mammals in Chile was performed by Neghme et al. in 1951 and involved the evaluation of Leptospira in brown rats (Rattus norvegicus) captured in a slaughterhouse from the Metropolitana region ${ }^{14}$. Rodentia was the most studied mammal order with 27 publications assessing the presence of viral and bacterial pathogens. A high number of articles were dedicated to investigate the long-tailed pygmy rice rat (Oligoryzomys longicaudatus), with 19 scientific publications involving the evaluation of Leptospira and hantavirus in this species. Order Carnivora (16), Chiroptera (12) and Cetartiodactyla (12) have also received attention from the scientific community. Only two studies involved a lagomorph species and a single article concerned a member of the Didelphimorphia order. No study determined infection with viral or bacterial 

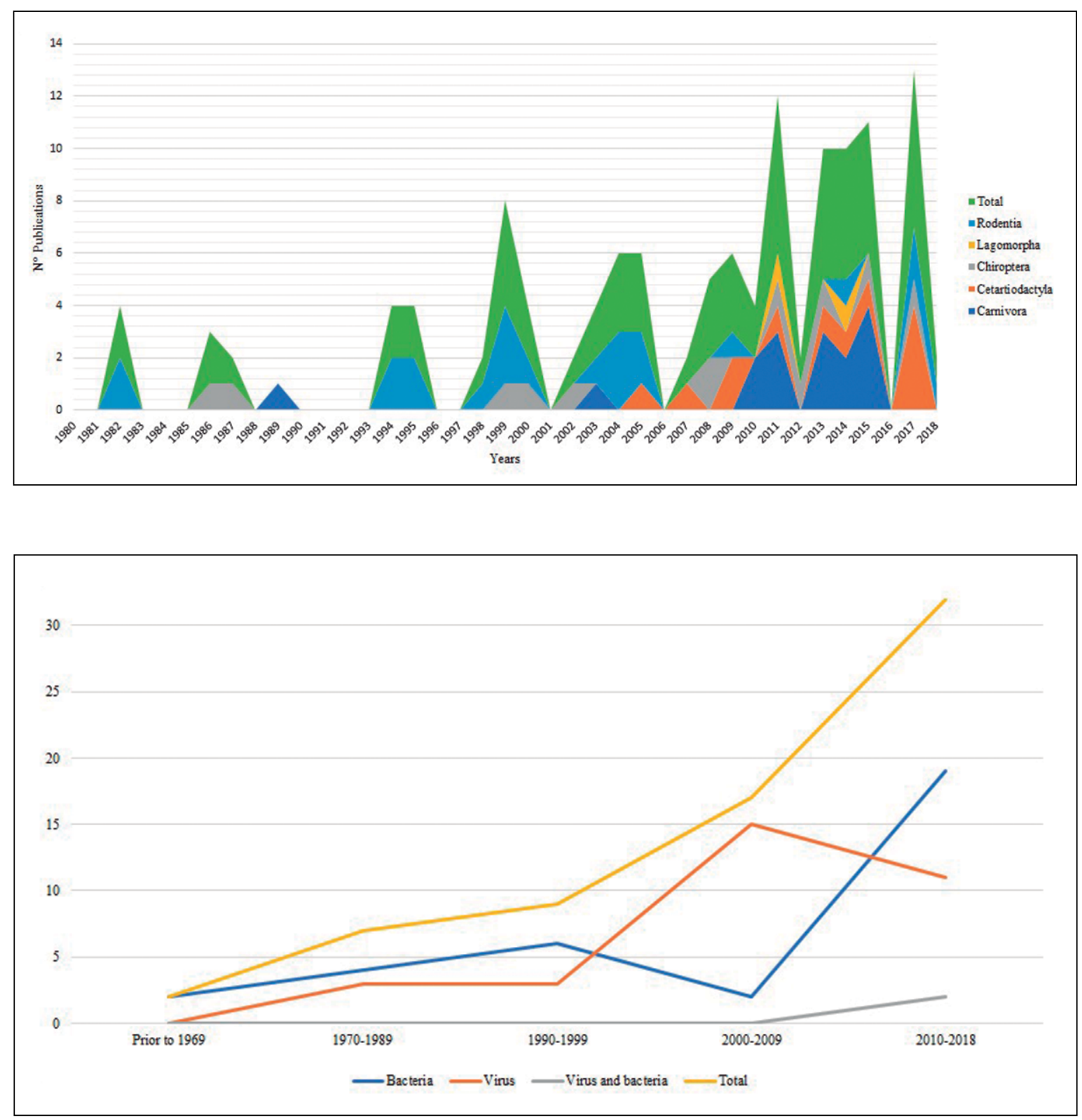

pathogens in members of the orders Paucituberculata, Microbiotheria and Xenarthra.

A high number of studies of viral and bacterial infections were focused in southern and central Chile, particularly from the Coquimbo to the Los Lagos regions. The most studied regions were the Los Ríos region with 24 studies, the Metropolitana region with 14 studies and the Los Lagos region with 13 studies. Only three studies in rabies and a single one in hantavirus were carried out in the Maule Region. Research studies including mammal species from the northern regions of Chile are lacking, with two studies in the Antofagasta region and a sigle one in the Tarapacá and the Atacama regions. Research has not been carried out in the Arica y Parinacota region. A total of 7 and 4 studies have been developed in the regions of Aysén and Magallanes, respectively.

Most studies applied serological methods for pathogen diagnosis in mammal hosts, such is the case of the distemper virus and parvovirus and the bacterium Brucella, which have been only assessed using serology. These methods were also commonly applied in research studies involving hantavirus in wild rodents. The application of molecular methods to detect pathogens in wild mammals has raised in the last two decades in Chile, which has
Figure 1. Number of scientific studies regarding viral or bacterial infections in different mammal orders from 1980 to 2018 .
Figure 2. Number of scientific studies assessing the prevalence of viral or bacterial infections in wild mammals in Chile from 1951 to 2018. 
been reflected in an increase in the use of these type of techniques for diagnosing viruses and bacteria in wild mammals. The use of other methods, such as direct immunofluresence, bacterial culture and histopathology has been mostly restricted for the specific diagnosis of certain pathogens.

\section{Discussion}

Wild mammals have played a crucial role as reservoirs of infectious diseases in developing countries and have been involved in the occurrence of spill-over epizootic events in human populations ${ }^{3}$. These events negatively impact public health systems in these countries and result in important economic losses ${ }^{3,4}$. In Chile, most scientists and governamental institutions have destined their efforts in studying those zoonotic agents considered as a serious threat to human health, such as Leptospira, rabies virus and hantavirus. Pathogens restricted to animal hosts and which do not represent a threat to humans (e.g., canine distemper virus) have only recently began to receive scientific attention and, in consequence, information available about them is much more limited.

\section{Leptospira}

Leptospirosis is a cosmopolitan zoonotic disease of great relevance for human health, particularly in developing and low-income countries, where sanitary conditions and resources destined for disease diagnosis and prevention are limited ${ }^{15}$. The agent responsible for causing this disease is Leptospira, a bacterial pathogen capable of infecting a variety of mammal hosts and survive for several months in the environment in areas with warm and humid climate conditions ${ }^{16}$.

Rodents play an important role in the maintenance and dissemination of pathogenic and non-pathogenic Leptospira to other mammal species in urban and rural areas of Chile, including humans and domestic animals ${ }^{17,18}$. To this date, evidence of infection by this pathogen have been shown in nine rodent species present in the country; the degu (Octodon degus), olive-colored akodont (Abrothrix olivaceus), long-haired akodont (Abrothrix longipilis), Darwin's leaf-eared mouse (Phyllothis darwini), longtailed pygmy rice rat (O. longicaudatus), black rat (Rattus rattus), brown rat ( $R$. norvergicus), house mouse (Mus musculus) and long-clawed mole mouse (Geoxus valdivianus $)^{17-27}$. Rattus norvegicus and $R$. rattus are particularly relevant reservoirs due to the high prevalence of Leptospira documented in these species in rural areas of the country ${ }^{18,27}$. This bacterium has been described in wild mammals in south-central areas of Chile, and more specifically in the Metropolitana, Los Ríos, Los Lagos and Aysén regions.
Reports indicating the presence of Leptospira in other mammal orders are scarce in comparison to the information available for rodents. This bacterium has been documented in only two carnivore species; the South American sea lion (Otaria flavescens) and the American mink (Neovison vison) $)^{9,28}$. The interaction between wild animals and domestic reservoirs (i.e., dogs and livestock) can act as an important mechanism for the ocurrence of leptospirosis cases in human inhabited environments ${ }^{29}$. Future studies dedicated to evaluate the role of wild species in the maintainance and transmission of Leptospira will make an important contribution to the understanding about the dynamics of this pathogens in natural and urban areas of the country.

\section{Rabies virus}

Rabies is a cosmopolitan zoonotic disease of great importance for public health worldwide ${ }^{30}$. All mammals are susceptible to rabies virus but only chiropterans and carnivores are capable of successfully maintain and transmit the infection in the long-term ${ }^{30}$. In Chile, confirmed cases of rabies are characterized by the ISP in different antigenic variants using specific monoclonal antibodies. Each variant represents an assemblage of viruses within a serotype that possesses defined antigenic properties ${ }^{31}$. This method of antigenic characterization of rabies has been widely applied in the country to study the geographical and temporal distribution of the virus ${ }^{32,33}$.

The first case of human rabies in Chile was reported in 1879 and surveillance in domestic and wild species has been performed since 1929 by the ISP (at the time called "Instituto Bacteriológico de Chile") $)^{34,35}$. The efforts of the ISP allowed to identify wildlife and domestic species prevalent to the virus, amongst them livestock, lagomorphs, rodents, carnivores and chiropterans ${ }^{33,34}$. However, active surveillance of rabies began following the first oubreak of this disease in bats, more specifically, in the brazilian free-tailed bat (Tadarida brasiliensis) in $1985^{33}$. After this event, rabies cases have been mainly reported in bats ${ }^{33,36}$.

To this date, five antigenic variants have been identified in Chile, including the canine antigenic variant $\mathrm{AgV} 2$ and four variants associated with insectivorous bats; the antigenic variant $\mathrm{AgV} 4$ Tadarida, antigenic variant AgV6 Lasiurus, antigenic variant AgV3 Myotis chiloensis and an antigenic variant $\mathrm{AgV}$ not typed for Histiotus ${ }^{33,37,38}$. The most common variant registered in Chile from 2008 to 2013 has been $\mathrm{AgV}^{39}$. Antigenic variants are described to be host-specific ${ }^{38,40}$, but recent studies suggest that there could be cross-species spillover transmission of rabies variants in bats $32,38,41,42$.

Six of the eleven species of bats distributed in the country have been described to be infected with the virus; the big-eared brown bat (Histiotus macrotus), small big- 
eared brown bat (Histiotus montanus), mouse-eared bat (M. chiloensis), eastern red bat (Lasiurus borealis), hoary bat (Lasiurus cinereus) and Brazilian free-tailed bat ( $T$. brasiliensis $)^{32,33,37,43}$. Considering the available scientific information, $T$. brasiliensis and $L$. cinereus remain the most relevant reservoirs of bat rabies in Chile ${ }^{32,36,37,41,43,44}$. Escobar et al. (2013) indicate that both T. brasiliensis and $L$. cinereus, and their respective antigenic variants of rabies (AgV4 and AgV6), share similar ecological niches in Chile and their distribution is limited by the presence of natural ecological barriers, such as the Andes Mountains to the east and the Pacific Ocean to the west ${ }^{32}$. Bat rabies seems to follow a seasonal pattern with peaks of positivity during hot season (October-March) and decrease in colder months ${ }^{33,39}$. This could be related to a reduction in bat activity during winter in the Southern hemisphere and therefore less chance of rabies transmission among bats and from bats to other susceptible species ${ }^{33,39,45}$.

The increase in population size and density of dogs, added to the presence of bat (mainly $T$. brasiliensis) in urban areas, have raised the risk of rabies transmission events from bats to dogs across the country ${ }^{46,47}$. This is particularly important for central Chile, which possesses a high number of bat-related antigenic variants and an increased richness of chiropteran species ${ }^{33}$. Highly populated human settlements, such as the large cities located in the Metropolitana, Maule, Biobío and Valparaíso regions, posses an elevated risk of rabies transmission between animals and humans and concentrate the higher number of human cases $^{33,39,47}$. Rabies cases have been reported in wild carnivores in Chile in years prior to $1990^{48}$, however, insectivorous bats are currently considered the most important reservoir of rabies in the country with the $97.31 \%(1339 / 1376)$ of positive cases reported by the ISP from 1985 to $2012^{32}$. The importance of bats as rabies reservoirs and the increasing population of stray dogs in in urban areas rise concern about the current risk of rabies transmission from bats to dogs and, ultimately, humans beens ${ }^{47}$.

\section{Hantavirus}

Seven rodent species have been found to be exposed or infected with the Andes virus in Chile; the olive-colored akodont (A. olivaceus), long-haired akodont (A. longipilis), Darwin's pericote ( $P$. darwini), Southern big-eared mouse (Loxodontomys micropus), black rat ( $R$. rattus), brown rat ( $R$. norvergicus) and long-tailed pygmy rice rat $(O \text {. longicaudatus })^{49-57}$. Reports of hantavirus belong to areas in south and central Chile, particularly from the Coquimbo to Magallanes regions. To this date, the presence of hantavirus in the country has been restricted solely to rodents and has not been possible to identify the virus in wild species from other orders, such as the case of marsupials and chiropterans ${ }^{54}$.
Oligoryzomys longicaudatus is the most important reservoir of the Andes virus in Chile, being responsible of disseminating the hantavirus to humans along its distributional ranged from the Copiapó to the Magallanes regions ${ }^{54,57-59}$. Oligoryzomys longicaudatus has been characterized as a high mobility species, which increases the risk of encountering humans throughout its wide home range $\left(320-4800 \mathrm{~m}^{2}\right)^{60}$. This species can be found in close proximity to urban areas, inhabiting humid environments and areas covered by bushes near water sources ${ }^{60}$. Increase in wild rodent population density in peri-urban areas has been linked to an elevation in the number of cases of hantavirus cardiopulmonary syndrome (HCPS) in humans ${ }^{51}$. It has been suggested that the explosive increase in the number of rodents during years of synchronized flowering of native bamboo, particularly Chusquea quila, might be implicated in the occurrence of hantavirus outbreaks in humans due to an increased available of food provided by these plants ${ }^{51,52}$. Most cases of hantavirus infection in Chile occur near towns in rural and peri-urban areas where O. longicaudatus is present and people are constantly exposed to become infected with the virus ${ }^{55,61,62}$.

\section{Mycobacterium}

Mycobacterium avium subp. paratuberculosis (MAP) is an important pathogen of cattle and small ruminants, responsible for causing important economic losses in animal production worldwide ${ }^{63}$. In Chile, native ungulates are at continuous risk of becoming infected with MAP due to the high prevalence of this pathogen reported in livestock, particularly in southern areas of the country ${ }^{64}$. The guanaco (Lama guanicoe), the Southern pudu (Pudu puda), the Chilean Huemul (Hippocamelus bisulcus) and the European hare (Lepus europaeus) have been reported to carry this bacterium in Chile ${ }^{65-69}$. MAP-infected guanacos did not display any health-related issues and European hares did not present microscopic or macroscopic lesions associated with the infection ${ }^{65,68}$. In the case of the huemul, the bacterium presented similar molecular characteristics to MAP isolates commonly reported in livestock in Chile, suggesting that the latter are spreading the infection to huemul populations ${ }^{70}$. The situation is concerning for this endangered deer species, particularly in central Chile, where the population of huemuls is facing severe conservation issues and its habitat is being disturbed by the presence of domestic animals ${ }^{71}$. Similarly, MAP infections were documented in three Southern pudus found in areas commonly occupied by dairy cattle ${ }^{67}$. Currently, there is no information about pathological findings of MAP infection in free-ranging pudúes, however, this bacterium was indicated as the cause of death for an individual maintained in captive settings ${ }^{66}$.

Infections with MAP have also been reported in introduced deer species in southern Chile, such as the red deer 
(Cervus elaphus) and fallow deer (Dama dama), which could be transmitting the pathogen to livestock and vice versa $^{72,73}$. The European wild boar (Sus scrofa) is currently distributed in rural and protected areas of south-central Chile and is considered as a carrier of MAP in Europe ${ }^{74,75}$. Currently, there have not been reports of MAP infection in this species in the country. The role that introduced ungulates species are playing in the transmission of MAP and other pathogens to native wildlife and livestock is a topic that still needs to be explored in Chile.

\section{Canine distemper virus}

Distemper is a viral disease prevalent in dogs all over the world and capable causing severe illness in wild carnivores ${ }^{76}$. A wide range of species from different families, such as the Canidae, Felidae, Hyaenidae, Mustelidae, Ursidae, Vivirridae and Procyonidae have been reported to be exposed or infected to canine distemper virus (CDV), in some cases, with major population declines ${ }^{76,77}$. CDV currently possesses an endemic status in urban and rural populations of dogs in Chile, with seroprevalences that range from 51 to $73 \%{ }^{10,78}$. Dogs have been indicated as the source of CDV outbreaks in populations of the South American gray fox (Lycalopex griseus) in central Chile ${ }^{10,79,81}$ and may be a threat to populations of the endangered Darwin's fox (Lycalopex fulvipes) in southcentral Chile ${ }^{82}$.

To this date, there are no study that applied methods to directly detect distemper virus in Chilean wildlife, however, serological surveys have found exposure to the virus in the American mink ( N. vison), South American sea lion (O. flavescens), South American gray fox (L. griseus) and Andean fox (Lycalopex culpaeus) $)^{8,9,79,80,81}$. There is no information about infection or exposure to CDV in wild felids and indigenous mustelids in the country.

Neglected pathogens and wild mammal species

This section includes pathogens that have received little attention from the scientific community in Chile and information about their presence in natural hosts is currently lacking or inexistent.

Parvoviruses have been detected in a wide range of wild carnivores around the world, belonging to the $\mathrm{Ca}$ nidae, Felidae and Mustelidae families ${ }^{83}$. In Chile, canine (CPV) and feline parvoviruses (FPV) are recognized affections of dogs and cats, respectively ${ }^{84}$. Serological assessments of CPV in L. culpaeus, L. griseus and $O$. flavescens have found past exposure to this virus ${ }^{9,10,80}$, meanwhile, there is no information about the exposure or infection with FPV in wild species. Both CPV and FPV, have shown to cause gastrointestinal affections in carnivores elsewhere ${ }^{83}$, but infections and potential pathological consequences of these viruses on Chilean species are still undetermined.

Like parvoviruses, information about retroviruses in
Chilean wildlife is lacking. Mora et al. (2015) found that guignas in Chiloé were infected with feline leukemia (FeLV) and feline immunodeficiency viruses (FIV) with no apparent clinical signs ${ }^{85}$. Nucleotide sequences obtained from FeLV and FIV in guignas were almost identical to those found in domestic cats, suggesting that cats may be playing an important role in the transmission of retroviruses to wild felids. Some feline species, such as the guigna, inhabit in areas close to human settlements and they ocassionally predate on poultry ${ }^{86}$, which increases the risk of interacting with infected domestic cats. Retroviruses have been detected in the cougar and other large felids in North America ${ }^{87}$, however, the presence of these viral agents in populations of cougars and most of the native wild felids species in Chile still needs to be addressed.

Information about viral and bacterial pathogens in native ruminants is very scarce. Bovine viral diarrhea virus (BVDV) was detected in the southern pudu and two Chilean huemuls were found to be exposed to the virus ${ }^{88,89}$. Similar to MAP, BVDV isolates from the southern pudu share molecular characteristics with viruses circulating in cattle, suggesting that livestock are acting as disseminators of pathogens to native wildlife in Chile ${ }^{70,88}$. Other pathogens present in livestock, such as bovine rhinotracheitis virus (BoHV-1) and Brucella spp., were assessed in the Chilean huemul using serological methods, but no individual were found to be exposed ${ }^{89}$.

There is no information about infections with viral or bacterial pathogens in aquatic carnivores, such as members of the Otariidae, Phocidae and Mustelidae families, except for the South American sea lion $(O$. flavescens) and the invasive American mink (N. vison). Furthermore, cetaceans have been mostly overlooked by the local scientific community, with only one viral disease being identified in Chile ${ }^{90,91}$. The Chilean dolphin (Cephalorhynchus eutropia), black porpoise (Phocoena spinipinnis), bottle-nosed dolphin (Tursiops truncatus) were found to present marks on their bodies typical of tattoo skin disease, an affection that might lead to neonatal mortality and have negative consequences on host population dynamics ${ }^{90,91}$. No other pathogens have been reported in cetaceans distributed in Chile, despite the fact that exposure to cetacean morbillivirus and Brucella sp. was described in species living along the Peruvian section of the Pacific Ocean ${ }^{92-94}$.

\section{Tick-borne pathogens}

Ticks are hematophagous ectoparasites of almost every terrestrial vertebrate and play an important role as vector of pathogens ${ }^{95}$. In Chile, viral and bacterial tick-borne pathogenic agents have been neglected and information available about the presence of Anaplasma platys ${ }^{96}$, Ehrlichia canis $^{97}$, "Candidatus Rickettsia andeanae"98 and Rickettsia felis ${ }^{99}$ is restricted to domestic mammals. 
However, a recent study identified "Candidatus Neoehrlichia chilensis" in wild rodent species from southern Chile using molecular methods ${ }^{100}$.

Recently, Borrelia burgdorferi was reported in Brazil, Mexico, Canada, Chile, Costa Rica, Colombia and Venezuela $^{101}$, however, most cases have been diagnosed based only on clinical and serological evidence, without a molecular characterization and isolation of the agent ${ }^{101}$. This has only been done by Ivanova et al. (2014), who reported Borrelia chilensis VA1, a new spirochete species from the Lyme group ${ }^{102}$. Additionally, Verdugo et al. (2017), found infection with $B$. chilensis in Ixodes stilesi ticks collected from the native southern pudu deer and suggests that $I$. stilesi may be playing a role in the maintainance of the spiroquete $^{103}$. Further studies are necessary to properly understand the mechanisms of natural transmission of this bacterium and the risks of infection for domestic animals and humans.

\section{Pathogen transmission between wildlife and domestic animals}

Pathogen transmission between wild species and livestock is bidirectional and affect both animal production and species conservation all over the world ${ }^{104}$. Factors, such as human encroachment into wildlife inhabited areas and the expansion and intensification of animal production systems to natural areas, can increase the risk for contact and pathogen transmission at the livestock-wildlife interface ${ }^{105}$. The interaction among livestock and wild species not only occurs in anthropogenically disturbed zones, but also in protected natural areas of Chile ${ }^{71,106}$. Pathogens, such as MAP, BVDV and Corynebacterium pseudotuberculosis, are being transmitted from farm animals to wild ungulates facing conservation issues ${ }^{70,88,107}$. For this reason, it is extremely relevant to understand the consequences that these infectious agents might have on the health of the affected species and the existent mechanisms for the transmission of diseases between livestock animals and wildlife.
Dogs are another threat for Chilean wildlife due to their predatory behaviour over native species and for their role as carriers of infectious pathogens ${ }^{108}$. Dogs inhabiting natural areas have been linked with outbreaks of viral diseases in carnivore populations that have resulted in mass mortality events of wild animals in the past ${ }^{109}$. Dogs populations have increased in size and density over the years in urban and rural areas of Chile, which might increase the possibility of encounters between wildlife and domestic dogs and the transmission of pathogenic $\operatorname{organisms}^{10,46,78,79,110}$.

\section{Conclusions}

To date, most publications have involved the study of zoonotic viral and bacterial pathogens in Chilean wild mammals. Non-zoonotic and vector-borne pathogens have been neglected by the local scientific community, despite their importance for wildlife conservation and public health, respectively. It is also concerning that a large number of studies have been performed in southern and central regions of Chile, while the development of research studies in the northern areas of the country have been limited. Research about viral and bacterial pathogens in Chilean wild mammals is still very scarce and further studies are necessary in order to properly understand the role that certain species might be playing as reservoir of infectious agents. The information gathered in future investigations dedicated to evaluate the presence of infection in wild mammals will establish the basis for more complex studies destined to understand the epidemiology and ecology of zoonotic and non-zoonotic infectious diseases in the country.

Acknowledgments. The authors would like to thank Mr. Andrés Felipe Peña for his assistance with the management of literature references. We acknowledge the support of FONDECYT no 1170972 


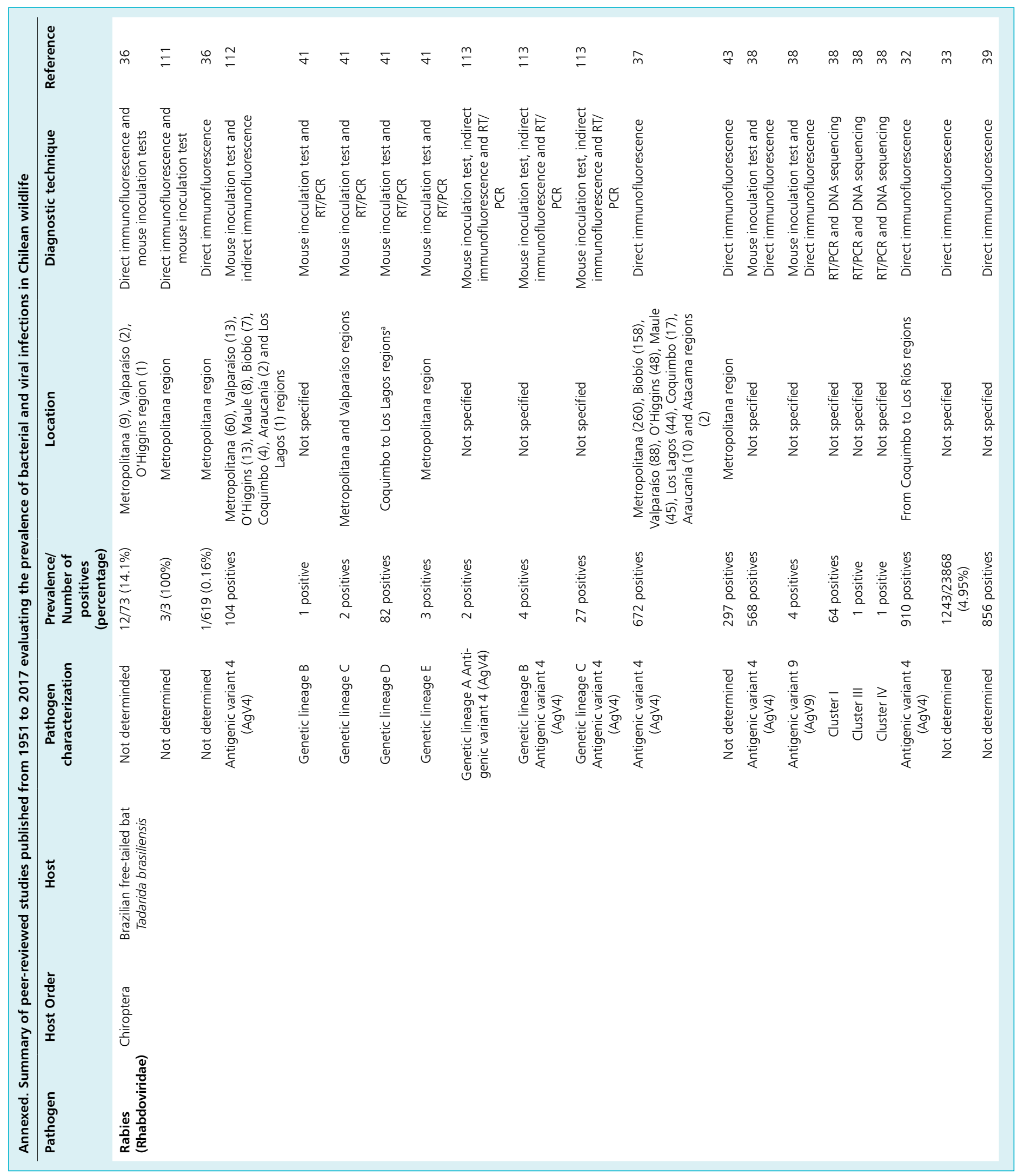




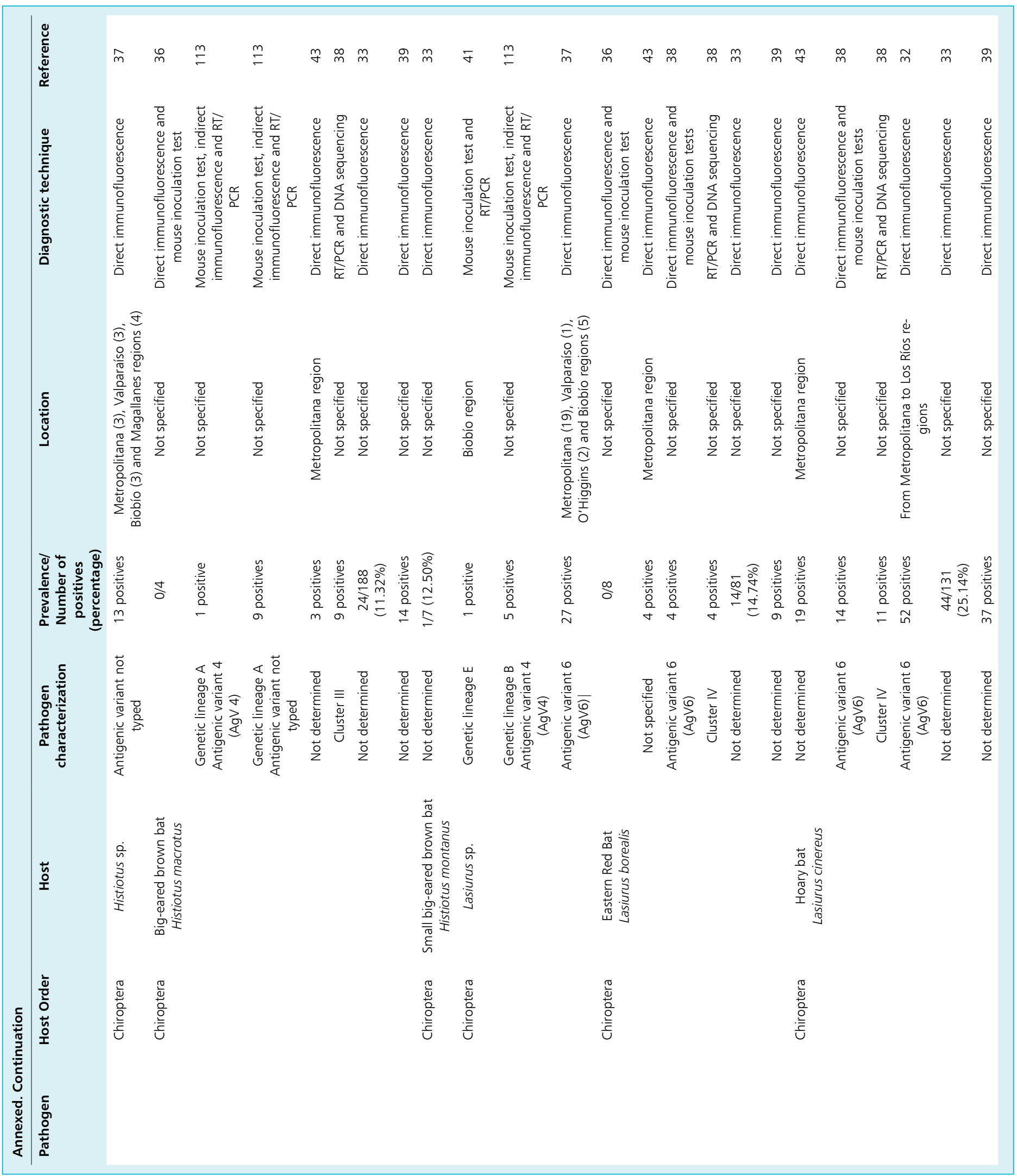




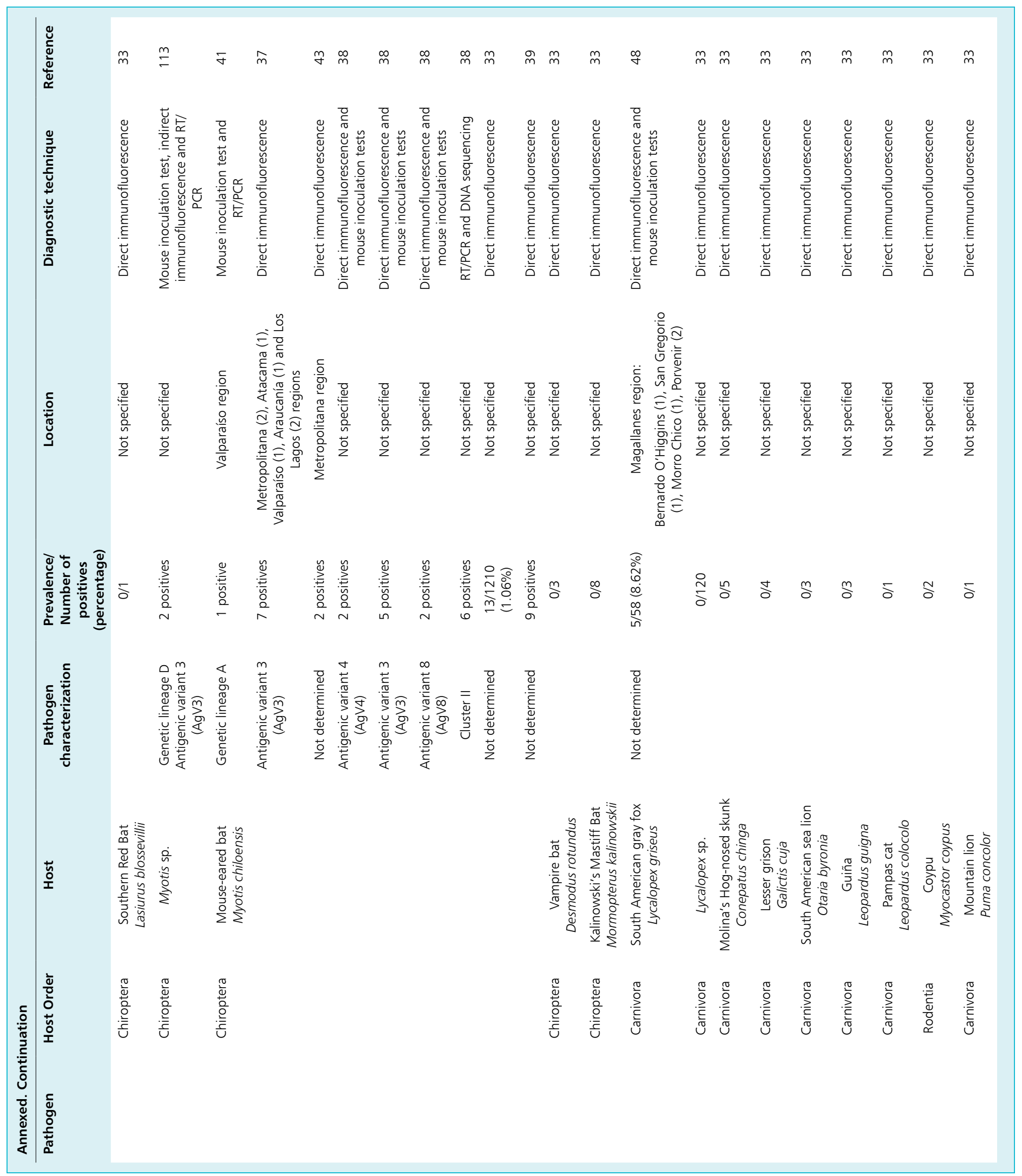




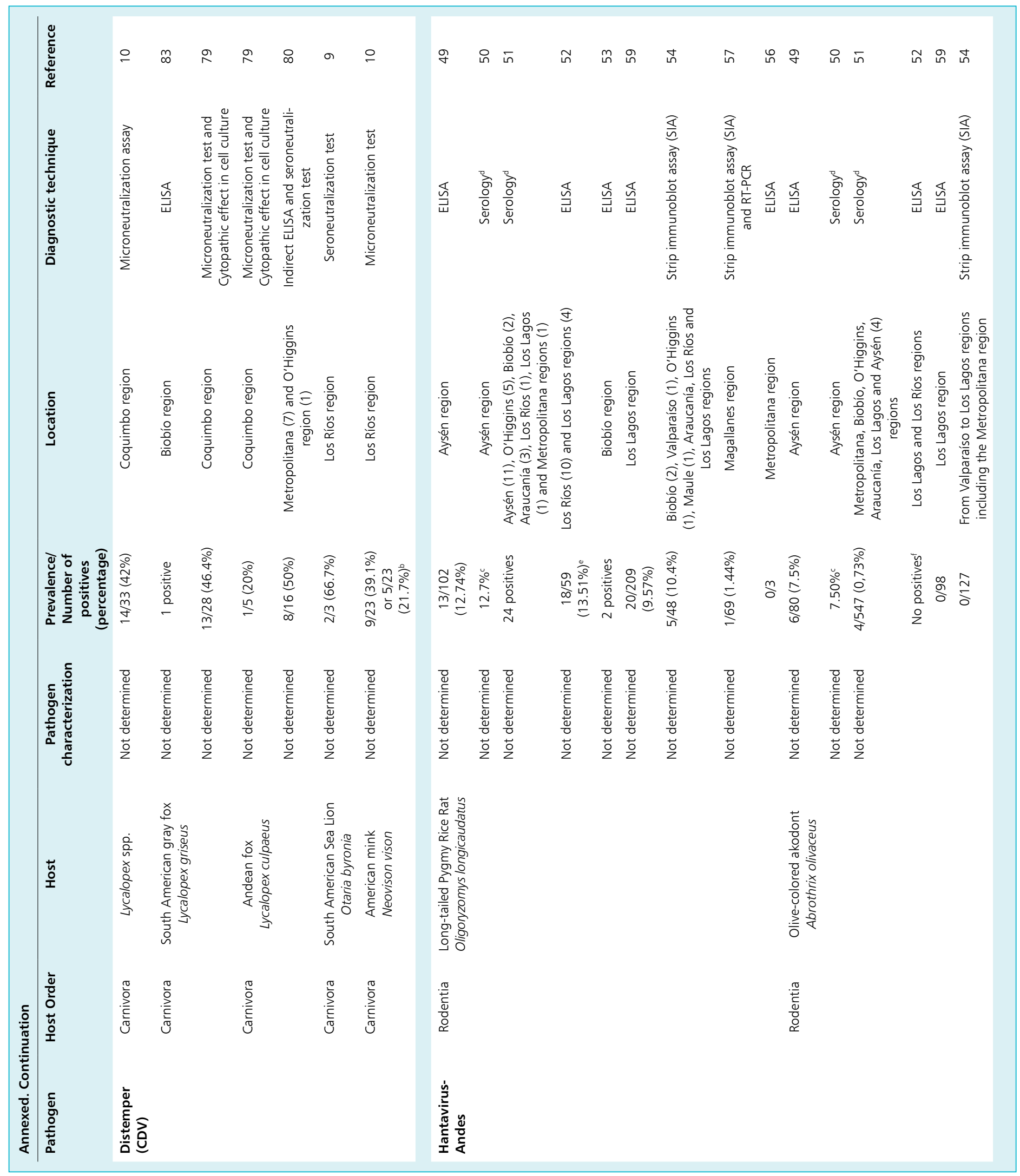




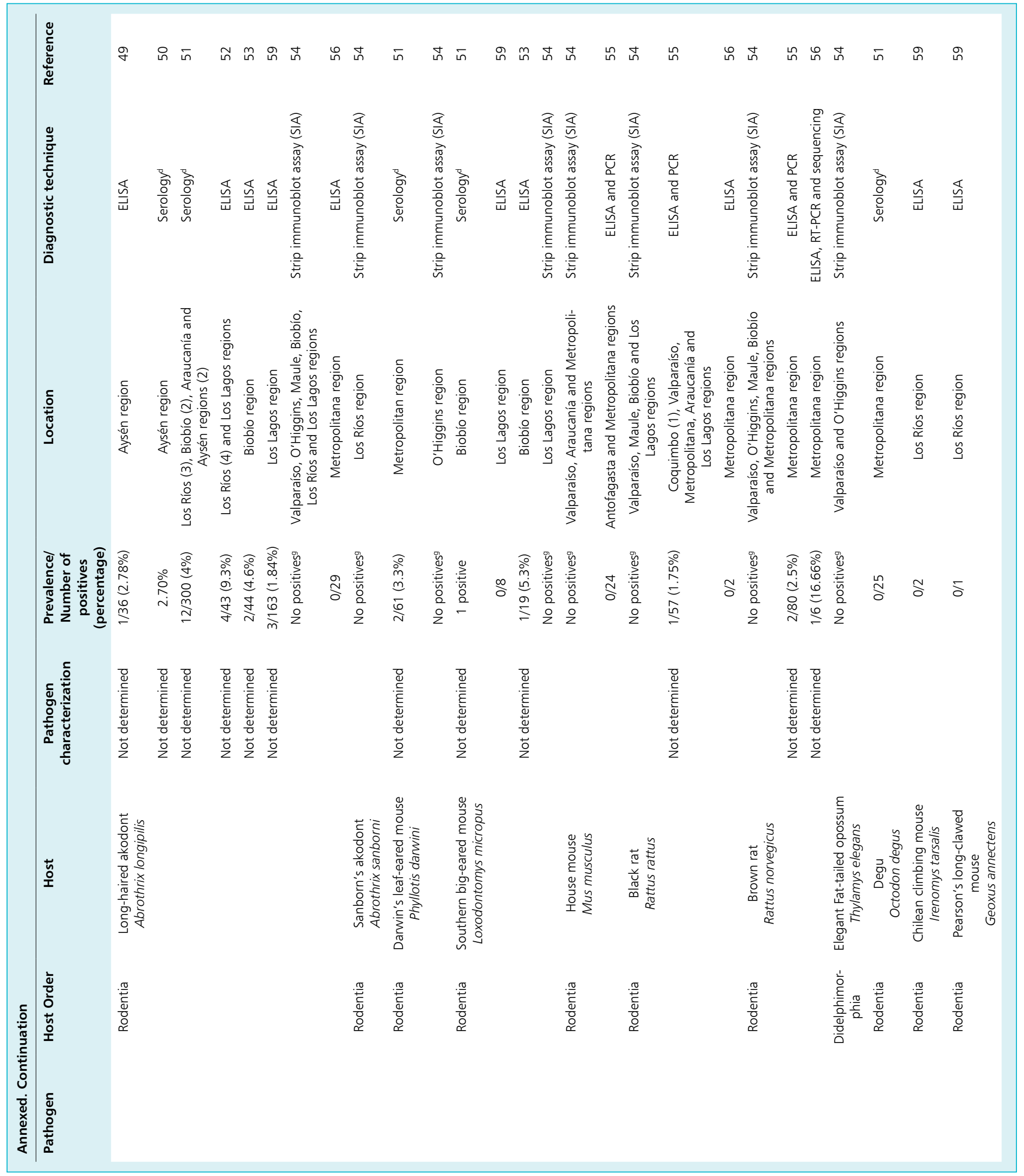




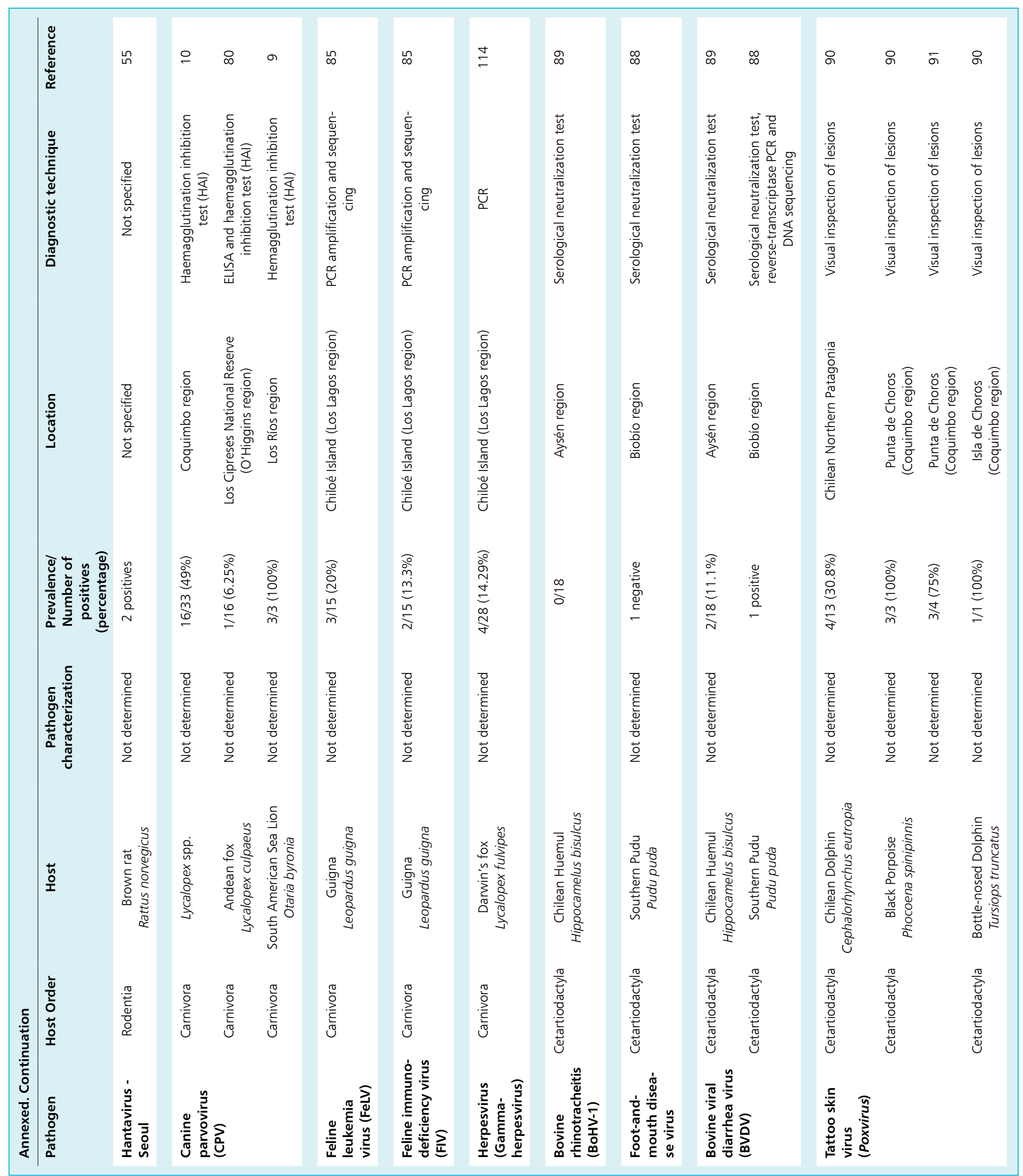




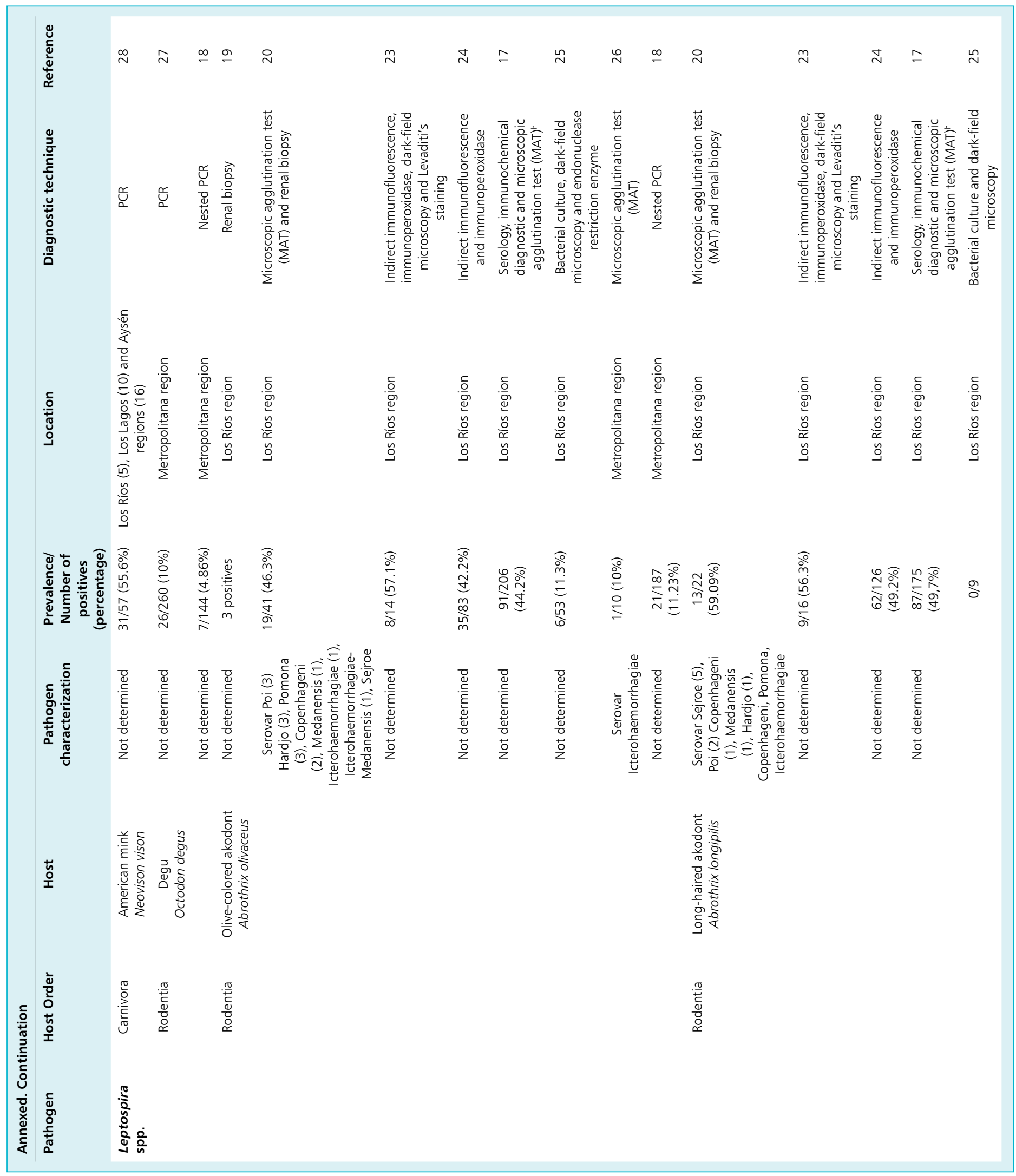




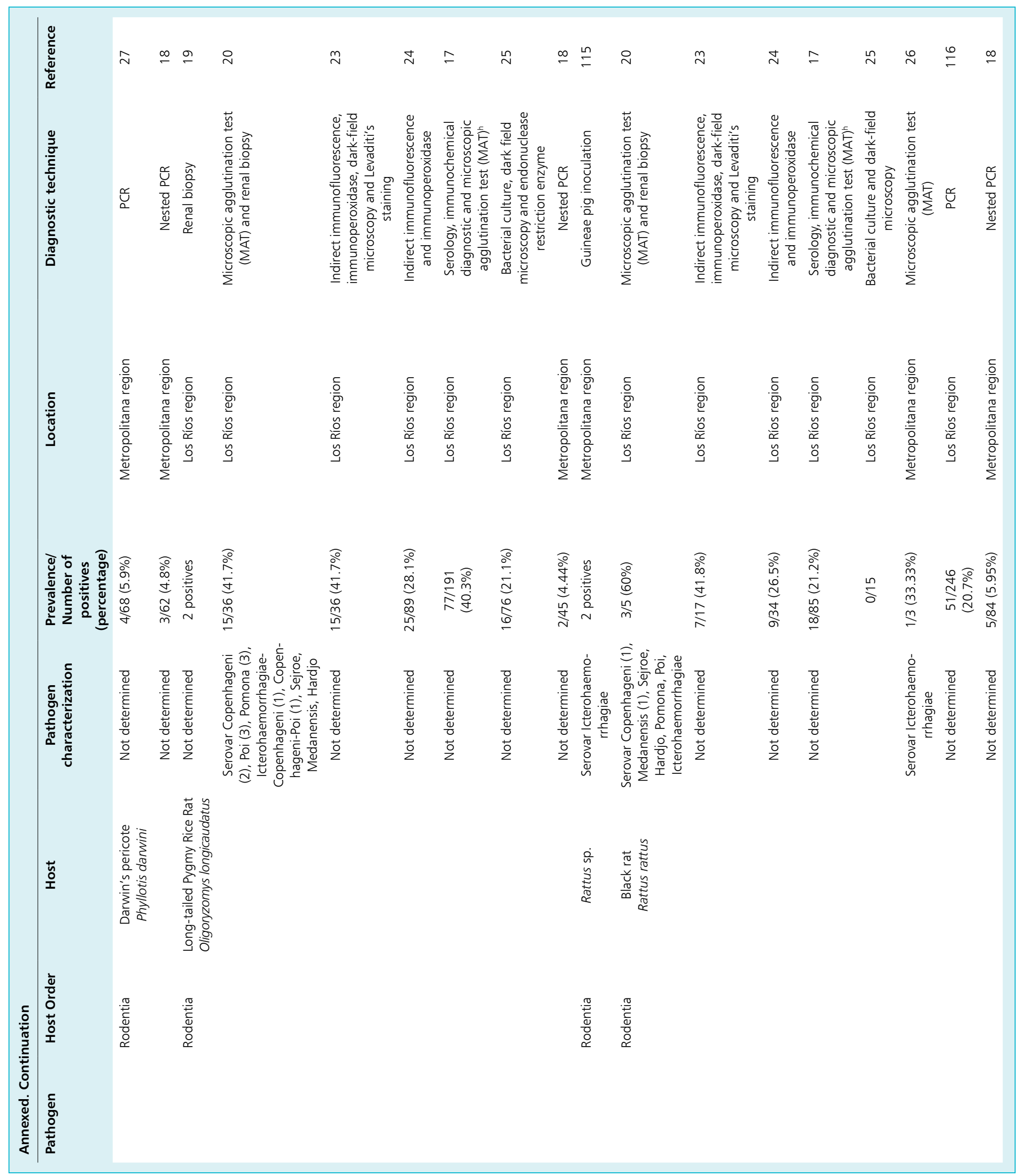




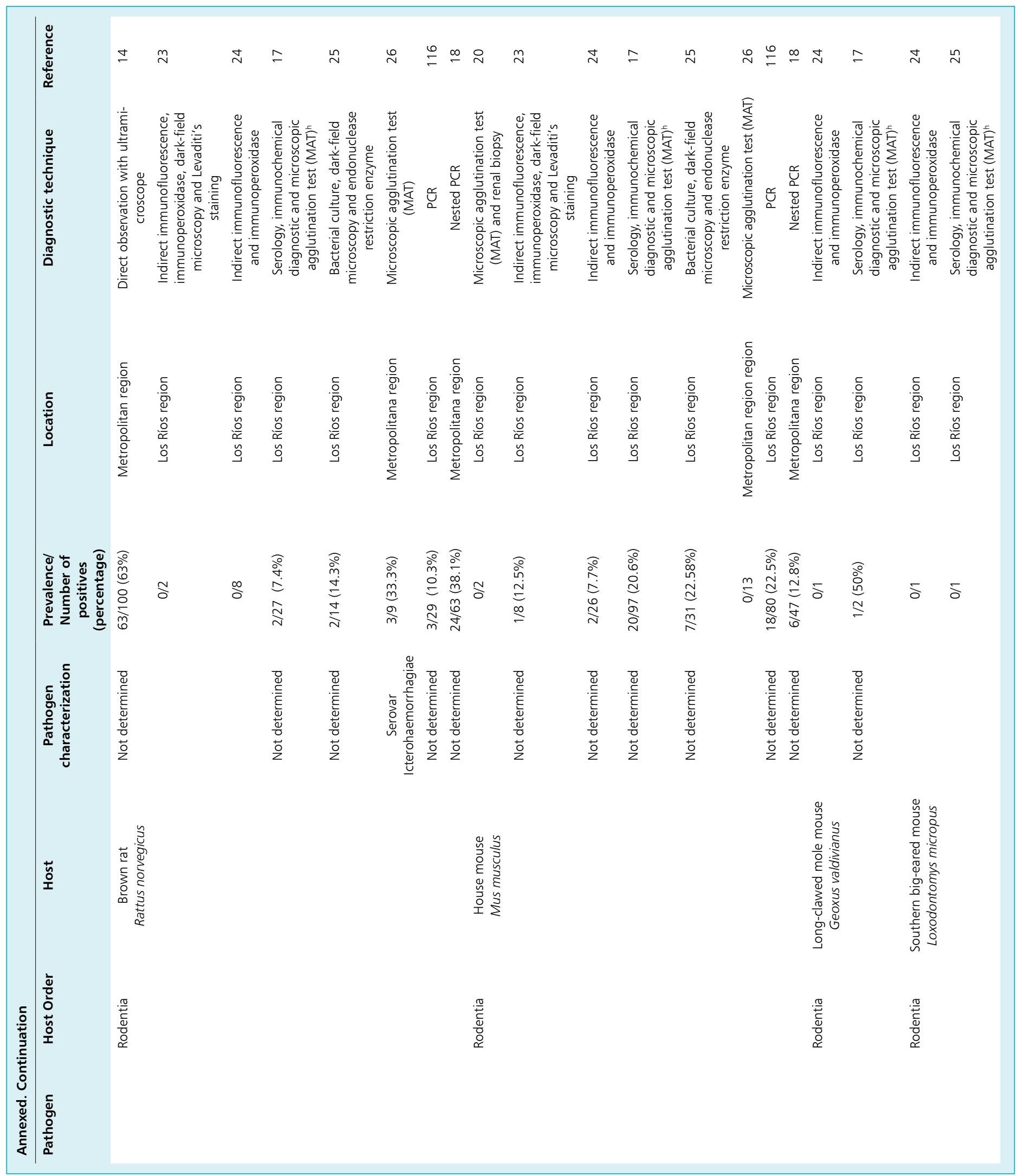




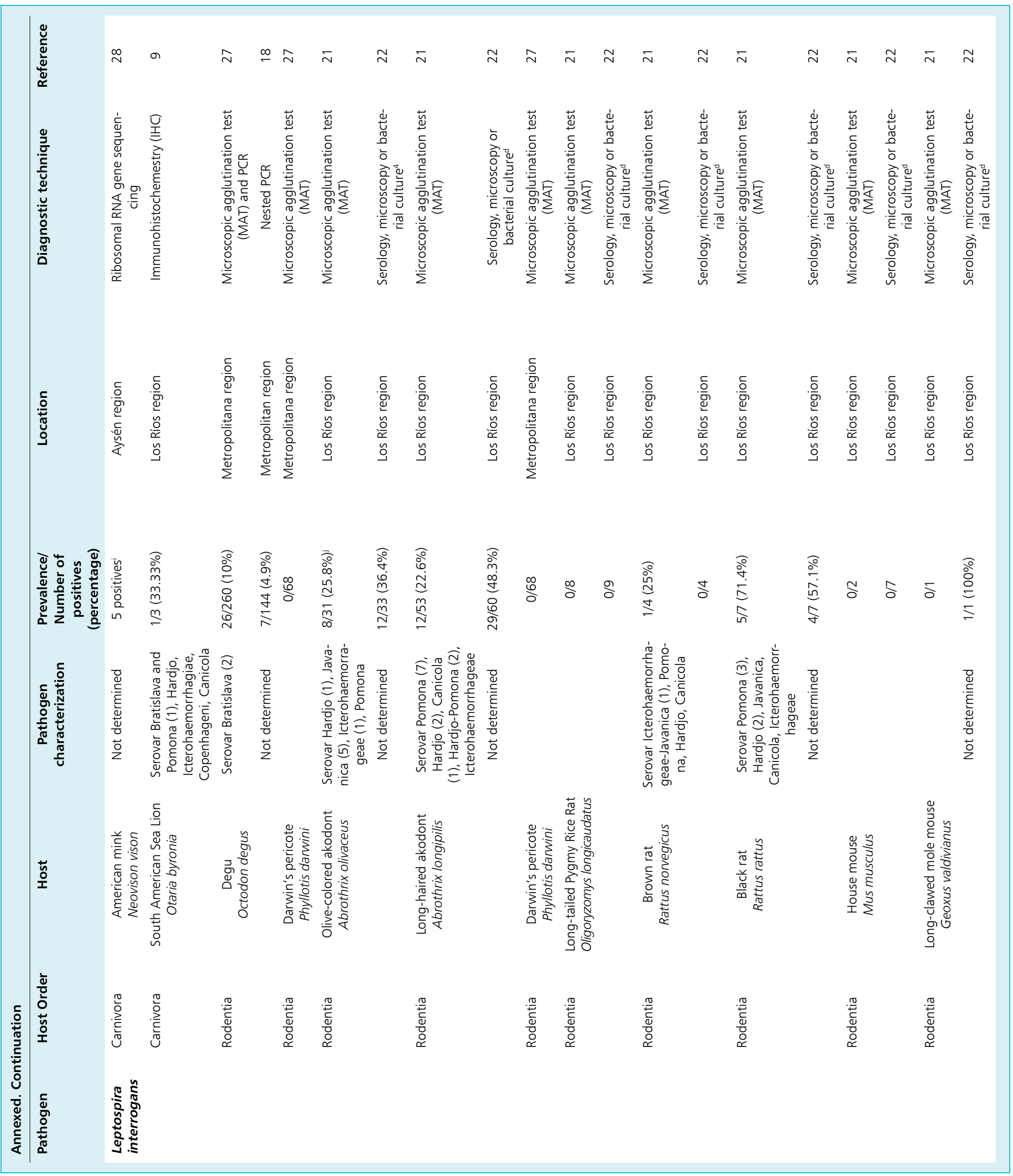




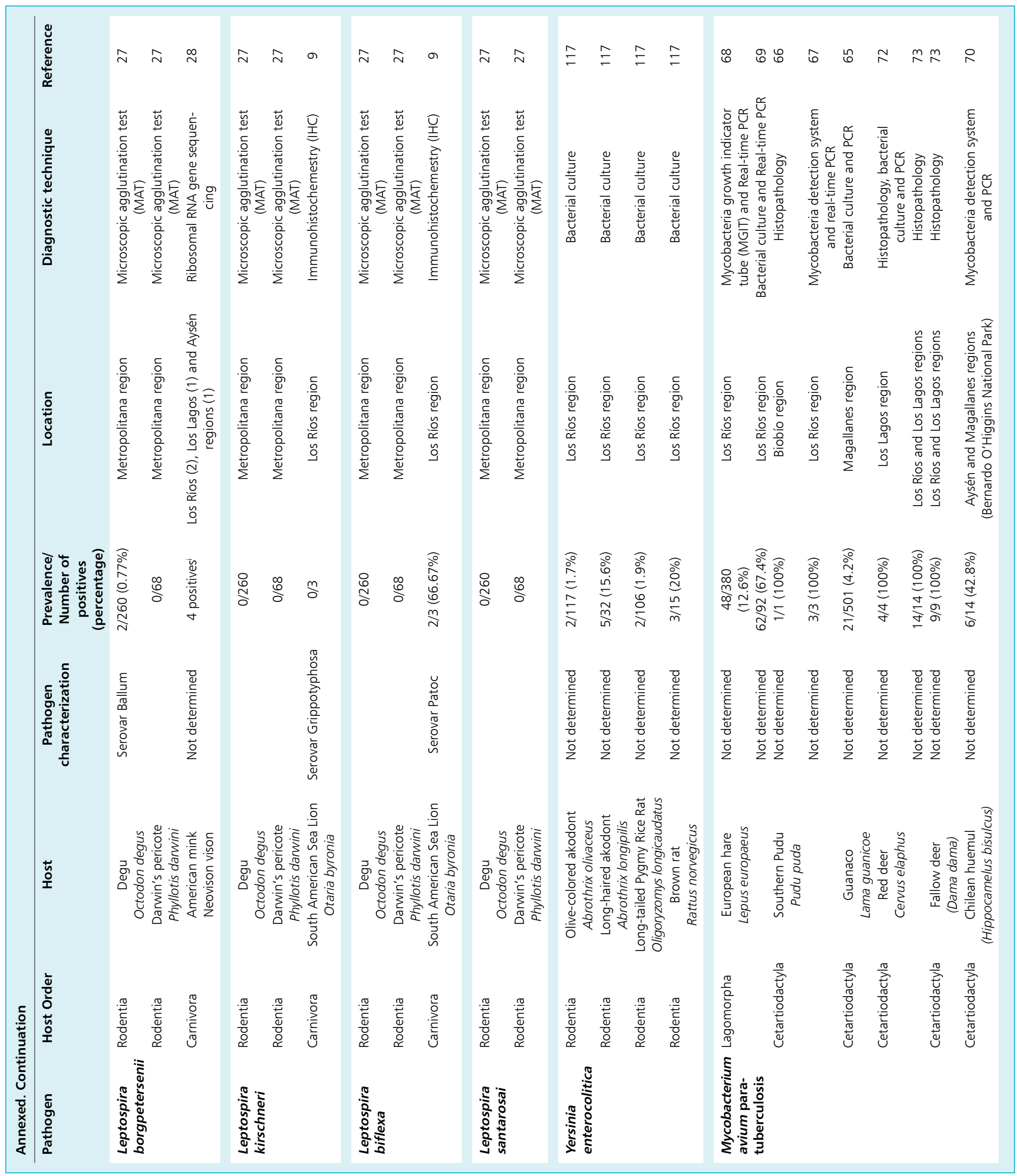




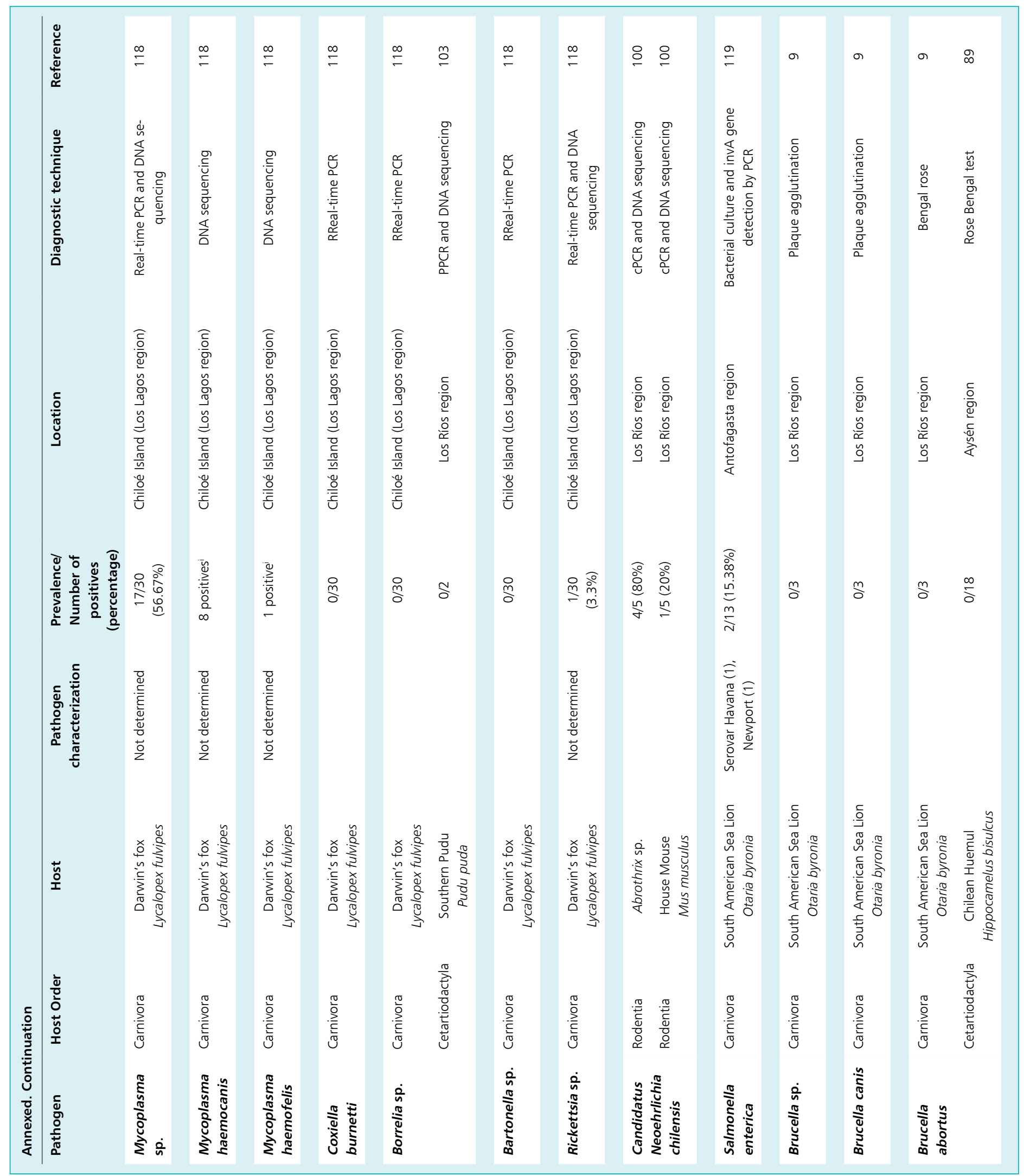




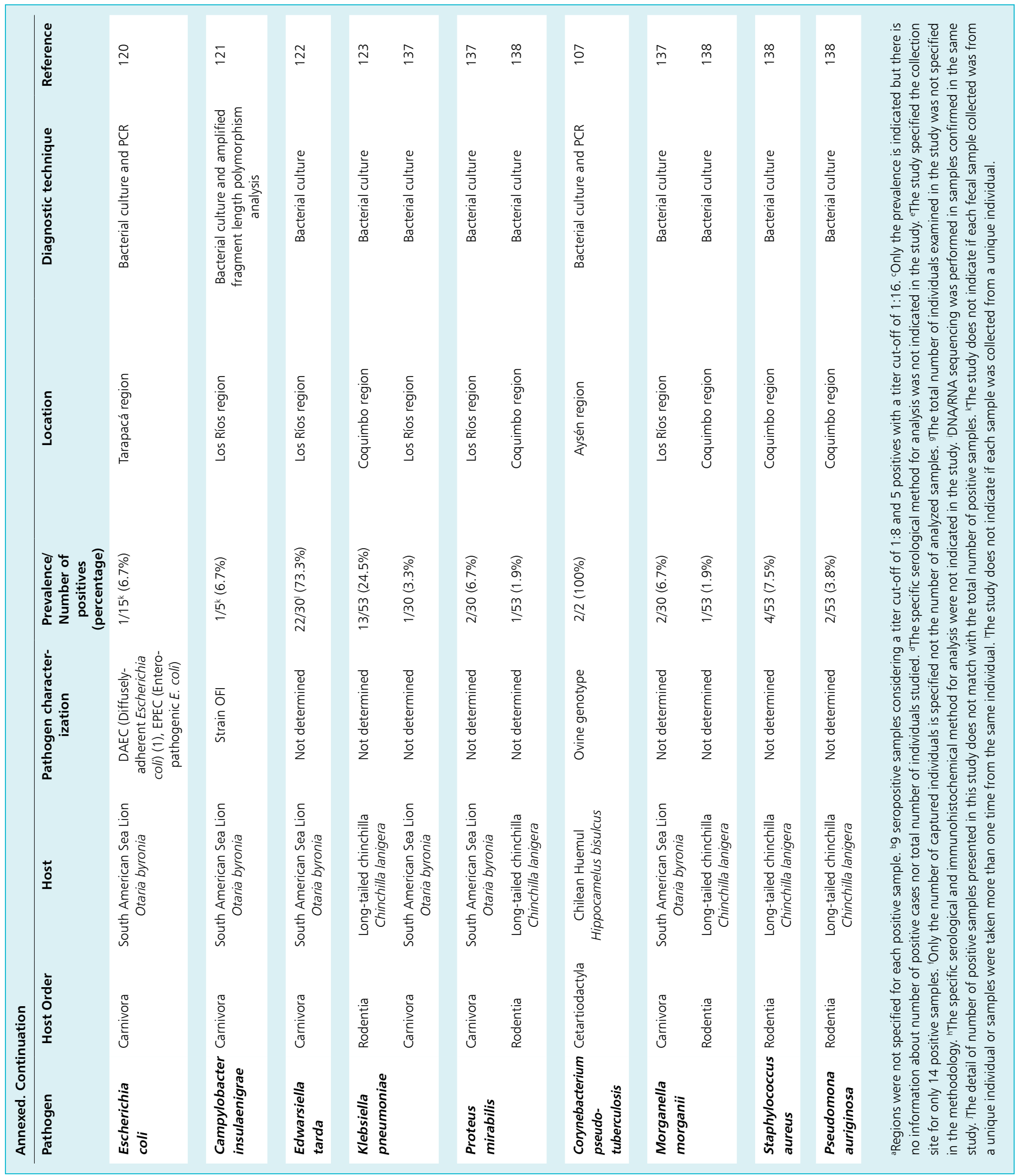




\section{References}

1.- Valenzuela-Sánchez A, Medina-Vogel G. Importancia de las enfermedades infecciosas para la conservación de la fauna silvestre amenazada de Chile. Gayana (Concepción) 2014; 78 (1): 57-69. doi: 10.4067/S071765382014000100008.

2.- Daszak P, Cunningham A A, Hyatt A D. Anthropogenic environmental change and the emergence of infectious diseases in wildlife. Acta Trop 2001; 78 (2): 103-16. PMID: 11230820 .

3.- Daszak P, Cunningham A A, Hyatt A D. Emerging infectious diseases of wildlife-threats to biodiversity and human health. Science 2000; 287 (5452): 443-9. PMID: 10642539.

4.- Coleman P G, Fèvre E M, Cleaveland S. Estimating the public health impact of rabies. Emerg Infect Dis 2004; 10 (1): 140-2. doi: 10.3201/eid1001.020774.

5.- Vaheri A, Henttonen H, Voutilainen L, Mustonen J, Sironen T, Vapalahti O. Hantavirus infections in Europe and their impact on public health. Rev Med Virol 2013; 23 (1): 35-49. doi: 10.1002/rmv.1722.

6.- Halliday J E, Allan K J, Ekwem D, Cleaveland S, Kazwala R R, Crump J A. One health: Endemic zoonoses in the tropics: a public health problem hiding in plain sight. Vet Rec 2015; 176 (9): 220-5. doi: 10.1136/vr.h798.

7.- Bradley C A, Altizer S. Urbanization and the ecology of wildlife diseases. Trends Ecol Evol 2007; 22 (2): 95-102. doi: 10.1016/j. tree.2006.11.001.

8.- $\quad$ Sepúlveda M A, Singer R S, Silva-Rodríguez E A, Eguren A, Stowhas P, Pelican K. Invasive American Mink: Lining pathogen risk between domestic and endangered carnivores. EcoHealth 2014; 11 (3): 409-19. doi: 10.1007/ s10393-014-0917-z.

9.- Sepúlveda M A, Seguel M, Alvarado-Rybak M, Verdugo C, Muñoz-Zanzi C, Tamayo R. Postmortem findings in four south American sea lions (Otaria byronia) from an urban colony in Valdivia, Chile. J Wild Dis 2015; 51 (1): 279-82. doi: 10.7589/2013-07-161.

10.- Acosta-Jamett G, Cunningham A A, Cleaveland S. Serosurvey of canine distemper virus and canine parvovirus in wild canids and domestic dogs at the rural interface in the Coquimbo Region, Chile. Eur J Wildl Res 2015; 61 (2): 329-32. https://doi.org/10.1007/ s10344-014-0886-0.

11.- Medina-Vogel G. Ecología de enfermedades infecciosas emergentes y conservación de especies silvestres. Arch Med Vet 2010; 42 (1): 11-24. https://scielo.conicyt.cl/pdf/amv/v42n1/ art03.pdf.

12.- Moher D, Liberati A, Tetzlaff J, Altman D G. Preferred reporting items for systematic reviews and meta-analyses: the PRISMA statement. Ann Intern Med 2009; 151 (4): $264-$ 9. PMID: 19622511.

13.- Kerry K R, Riddle M. Health of Antarctic wildlife: a challenge for science and policy. Springer Science \& Business Media. 2009. New York.

14.- Neghme A, Jarpa A, Agosin M, Christen R. Indice de infestación por leptospiras en las ratas (Rattus norvegicus) del matadero municipal de Santiago, Chile. Bol Inf Parasitol Chil 1951; 6: 6-7.

15.- Abela-Ridder B, Sikkema R, Hartskeerl R A. Estimating the burden of human leptospirosis. Int J Antimicrob Agents 2010; 36: S5-S7. doi: 10.1016/j.ijantimicag.2010.06.012.

16.- Levett P N. Leptospirosis. Clin Micrbiol Rev 2001; 14 (2): 296-326. doi: 10.1128/ CMR.14.2.296-326.2001.

17.- Zamora J, Riedemann S. Animales silvestres como reservorios de leptospirosis en Chile: Una revisión de los estudios efectuados en el país. Arch Med Vet 1999a; 31 (2): 151-6. http://dx.doi.org/10.4067/S0301732X1999000200001.

18.- Correa J P, Bucarey S A, Cattan P E, LandaetaAqueveque C, Ramírez-Estrada J. Renal carriage of Leptospira species in rodents from Mediterranean Chile: The Norway rat (Rattus norvegicus) as a relevant host in agricultural lands. Acta Trop 2017a; 176: 105 8. doi: 10.1016/j.actatropica.2017.07.032.

19.- Zamora J, Murúa R. Infecciones por Leptospira en roedores silvestres. Comunicación preliminar. Arch Med Vet 1976; 8: 424-6.

20.- Riedemann S, Zamora J. Leptospirosis en pequeños roedores en el área rural de Valdivia. Zoonoses Public Health 1982; 29 (10): 764-8. https://doi.org/10.1111/j.1439-0450.1982. tb01195.x.

21.- Riedemann S, Cabezas X, Zamora J. Detección de aglutininas antileptospira en roedores silvestres del área rural de Valdivia, Avances en Ciencias Veterinarias 1994; 9 (1): 162-4. doi: 10.5354/0719-5273.2010.6139.

22.- Zamora J, Riedemann S, Cabezas X. Relación entre algunos aspectos ambientales y la infección por $L$. Interrogans en roedores de la provincia de Valdivia. Medio Ambiente 1994; 12: 3-8.

23.- Zamora J, Riedemann S, Cabezas X, Vega S. Comparación de cuatro técnicas microscópicas para el diagnóstico de leptospirosis en roedores silvestres en el área rural de Valdivia, Chile. Rev Lat Microbiol 1995a; 37: 267-2. PMID: 8850345.

24.- Zamora J, Riedemann S, Cabezas X, Lovera P. Leptospirosis de roedores silvestres en el área rural de Valdivia. Pesquisa de Leptospira interrogans mediante inmunofluorescencia e inmunoperoxidasa. Arch Med Vet 1995b; 27 (1): $115-8$.

25.- Zamora J, Riedemann S. Aislamiento y sobrevivencia de leptospiras en tejido renal de roedores silvestres. Arch Med Vet 1999b; 31: 103-7. http://dx.doi.org/10.4067/S0301732X1999000100011.

26.- Perret C, Abarca K, Dabanch J, Solari V, García P, Carrasco S, et al. Prevalencia y presencia de factores de riesgo de leptospirosis en una población de riesgo de la Región Metropolitana. Rev Med Chile 2005; 133 (4): 426-31. doi: /S0034-98872005000400005

27.- Correa J P, Bacigalupo A, Botto-Mahan C, Bucarey S, Cattan P E, García de Cortazar R, et al. Natural infection of Leptospira species in the native rodents Degu (Octodon degus) and Darwin's Pericote (Phyllotis darwini) in mediterranean Chile. J Wild Dis 2017b; 53: 677-80. doi: 10.7589/2016-11-248.

28.- Barros M, Sáenz L, Lapierre L, Núñez C, Medina-Vogel G. High prevalence of pathogenic Leptospira in alien American mink (Neovison vison) in Patagonia. Rev Chil Hist Nat 2014; 87(1): 19. http://dx.doi.org/10.1186/ S40693-014-0019-X.

29.- Lelu M, Muñoz-Zanzi C, Higgins B, Galloway R. Seroepidemiology of leptospirosis in dogs from rural and slum communities of Los Rios Region, Chile. BMC Vet Res 2015; 11 (1): 31. doi: 10.1186/s12917-015-0341-9.

30.- Hankins D G, Rosekrans J A. Overview, prevention, and treatment of rabies. Mayo Clin Proc 2004; 79 (5): 671-6. doi: 10.1016/S00256196(11)62291-X

31.- Rupprecht C E, Hanlon C A, Hemachudha T. Rabies re-examined. Lancet Infect Dis 2002; 2 (6): 327-43. PMID: 12144896.

32.- Escobar L E, Peterson A T, Favi M, Yung V, Pons P J, Medina-Vogel G. Ecology and geography of transmission of two bat-borne rabies lineages in Chile. PLoS Negl Trop Dis 2013; 7 (12): e2577. doi: 10.1371/journal. pntd.0002577.

33.- Escobar L E, Restif O, Yung V, Favi M, Pons D J, Medina-Vogel G. Spatial and temporal trends of bat-borne rabies in Chile. Epidemiol Infect 2015; 143 (7): 1486-94. doi: 10.1017/ S095026881400226X. Epub 2014 Aug 28.

34.- Favi M, Durán J C. Epidemiología de la rabia en Chile (1929-1988) y perspectivas en mamíferos silvestres. Avances en Ciencias Veterinarias 1991; 6 (1): 13-21. doi: 10.5354/0719-5273.2010.4623.

35.- Laval E, Lepe P. Una visión histórica de la rabia en Chile. Rev Chilena Infectol 2008; 25 (2): S2-S7. doi: 10.4067/S071610182008000200014.

36.- Favi M, Catalán R. Rabies in bats in Chile. Avances en Ciencias Veterinarias 1986, 1: 73 6. doi: 10.5354/0719-5273.2010.4439.

37.- Favi M, Rodríguez L, Espinosa C, Yung V. Rabia en Chile: 1989-2005. Rev Chilena Infectol 2008; 25 (2): s8-s13. doi: 10.4067/ S0716-10182008000200015. 
38.- Yung V, Favi M, Fernández J. Typing of the rabies virus in Chile, 2002-2008. Epidemiol Infect 2012; 140 (12): 2157-62. doi: 10.1017/ S0950268812000520.

39.- Alegría-Morán R, Miranda D, Barnard M, Parra A, Lapierre L. Characterization of the epidemiology of bat-borne rabies in Chile between 2003 and 2013. Prev Vet Med 2017: 143; 30-8. doi: 10.1016/j. prevetmed.2017.05.012.

40.- Piñero C, Dohmen F G, Beltrán F, Martínez L, Novaro L, Russo S, et al. High diversity of rabies viruses associated with insectivorous bats in Argentina: presence of several independent enzootics. PLoS Negl Trop Dis 2012; 6 (5): e1635. doi: 10.1371/journal. pntd.0001635.

41.- de Mattos C A, Favi M, Yung V, Pavletic C, de Mattos C C. Bat rabies in urban centers in Chile. J Wild Dis 2000; 36 (2): 231-40. doi: 10.7589/0090-355836.2.2310.

42.- Cisterna D, Bonaventura R, Caillou S, Pozo O, Andreau M L, Dalla Fontana L, et al. Antigenic and molecular characterization of rabies virus in Argentina. Virus Res 2005; 109 (2): 139-47. doi: 10.1016/j. virusres.2004.10.013.

43.- Favi M C, Bassaletti A C, López J D, Rodríguez L A, Yung V. Descripción epidemiológica del reservorio de rabia en murciélagos de la Región Metropolitana. Chile. 2000-2009. Rev Chilena Infectol 2011; 28 (3): 223-8. doi: 10.4067/s071610182011000300004.

44.- Díaz A M, Papo S, Rodríguez A, Smith J S. Antigenic analysis of rabies-virus isolates from Latin America and the Caribbean. Zentralbl Veterinarmed B. 1994; 41 (3): 153-6.

45.- Bozinovic F, Contreras L C, Rosenmann M, Torres-Mura J C. Bioenergética de Myotis chiloensis (Quiroptera: Vespertilionidae). Rev Chil Hist Nat 1985; 58: 39-45. http://rchn.biologiachile.cl/pdfs/1985/1/ Bozinovic_et_al_1985.pdf.

46.- Acosta-Jamett $\mathrm{G}$, Cleaveland $\mathrm{S}$, Cunningham AA. Demography of domestic dogs in rural and urban areas of the Coquimbo region of Chile and implications for disease transmission. Prev Vet Med 2010; 94 (3): 272-81. doi: 10.1016/j. prevetmed.2010.01.002.

47.- Astorga F, Escobar L E, Poo-Muñoz D A, Medina-Vogel G. Dog ownership, abundance and potential for bat-borne rabies spillover in Chile. Prev Vet Med 2015; 118 (4): 397-405. doi: 10.1016/j.prevetmed.2015.01.002.

48.- Durán J C, Favi M. Rabia en zorro gris (Pseudalopex griseus) patagónico. Magallanes. Chile. Avances en Ciencias Veterinarias 1989; 4: 146-52. doi: 10.5354/0719-5273.2010.4548

49.- Toro J, Vega J D, Khan A S, Mills J N, Padula $\mathrm{P}$, Terry W, et al. An outbreak of hantavirus pulmonary syndrome, Chile, 1997. Emerg Infect Dis 1998; 4 (4): 687-94. doi: 10.3201/ eid0404.980425.

50.- Baró M, Vergara J, Navarrete M. Hantavirus en Chile: revisión y análisis de casos desde 1975. Rev Med Chile 1999; 127 (12): 1513-23. doi: 10.4067/S0034- 98871999001200015.

51.- Pavletic C. Hantavirus: Su distribución geográfica entre los roedores silvestres de Chile. Rev Chilena Infectol 2000; 17(3): 18696. doi: 10.4067/S0716- 10182000000300002 .

52.- Murúa R, Navarrete M, Cádiz R, Figueroa R, Padula P, Zaror L, et al. Síndrome pulmonar por Hantavirus: situación de los roedores reservorios y la población humana en la Décima Región, Chile. Rev Med Chile 2003; 131 (2): 169-76. doi: 10.4067/ S0034 98872003000200006 .

53.- Ortiz J C, Venegas W, Sandoval J A, Chandía $\mathrm{P}$, Torres F. Hantavirus en roedores de la Octava Región de Chile. Rev Chil Hist Nat 2004; 77 (2): 251-6. doi: 10.4067/S0716078X2004000200005.

54.- Torres-Pérez F, Navarrete-Droguett J, Aldunate R, Yates T L, Mertz G J, Vial P A, et al. Peridomestic small mammals associated with confirmed cases of human hantavirus disease in southcentral Chile. Am J Trop Med Hyg 2004; 70 (3): 305-9. PMID: 15031522.

55.- Lobos G, Ferres M, Palma R E. Presencia de los géneros invasores Mus y Rattus en áreas naturales de Chile: un riesgo ambiental y epidemiológico. Rev Chil Hist Nat 2005; 78 (1): 113-24. doi: 10.4067/ S0716078X2005000100008.

56.- Fernández J, Villagra E, Yung V, Tognarelli J, Araya P, Mora J, et al. Identificación de Hantavirus Andes en Rattus norvegicus. Arch Med Vet 2008; 40 (3): 295-8. doi: 10.4067/ S0301-732X2008000300011.

57.- Belmar-Lucero S, Godoy P, Ferres M, Vial P, Palma R E. Range expansion of Oligoryzomys longicaudatus (Rodentia, Sigmodontinae) in Patagonian Chile, and first record of Hantavirus in the region. Rev Chil Hist Nat 2009; 82 (2): 265-75. doi: 10.4067/ S0716078X2009000200008.

58.- Gallardo M, Palma R, Systematics of Oryzomys longicaudatus (Rodentia, Muridae) in Chile. J Mammal 1990; 71: 333-42. doi: $10.2307 / 1381943$

59.- Padula P, Figueroa R, Navarrete M, Pizarro E, Cadiz R, Jofre C, et al. Transmission study of Andes Hantavirus infection in wild Sigmodontine rodents. J Virol 2004; 78 (21): 11972-9. doi: 10.1128/JVI.78.21.1197211979.2004

60.- Murúa R, González LA, Meserve P L. Population ecology of Oryzomys longicaudatus philippii (Rodentia: Cricetidae) in southern Chile. J Anim Ecol 1986; 55 (1): 281-93. doi: $10.2307 / 4708$
61.- Morales JV. Diagnóstico y manejo del síndrome cardiopulmonar por hantavirus. Chile-2007. Rev Chil Infect 2009; 26 (1): 68 86. doi: $10.4067 /$ S0716- 10182009000100013.

62.- Mackelprang R, Dearing D, Jeor S. High prevalence of Sin Nombre virus in rodent populations, central Utah: A consequence of human disturbance? Emerg Infect Dis 2001; 7: 480-1. doi: 10.3201/ eid0703.010328.

63.- Kennedy DJ, Benedictus G. Control of Mycobacterium avium subsp. paratuberculosis infection in agricultural species. Rev Sci Tech 2001; 20 (1): 151-79. PMID: 11288510.

64.- Kruze J, Monti G, Schulze F, Mella A, Leiva S. Herd-level prevalence of Map infection in dairy herds of southern Chile determined by culture of environmental fecal samples and bulk-tank milk qPCR. Prev Vet Med 2013; 111 (3): 319-24. doi: 10.1016/j. prevetmed.2013.05.011

65.- Salgado M, Herthnek D, Bölske G, Leiva S, Kruze J. 2009. First isolation of Mycobacterium avium subsp. paratuberculosis from wild guanacos (Lama guanicoe) on Tierra del Fuego Island. J Wild Dis 2009; 45 (2): 295 301. doi: 10.7589/0090-3558-45.2.295

66.- González-Acuña D, Neira-Ramírez V, Moreno-Salas L, Quezada M. First report of paratuberculose in Southern Pudu deer (Artyodactila: Cervidae). Arq Bras Med Vet Zootec 2011; 63 (4): 1025-7. doi: 10.1590/ S0102-09352011000400033.

67.- Salgado M, Aleuy O A, Sevilla I A, Troncoso E. Detection of Mycobacterium avium subsp. paratuberculosis in a cattle/pudu interface. Arq Bras Med Vet Zootec 2015; 67 (5): 1205-9. doi: 10.1590/1678-4162-7530.

68.- Salgado M, Manning E J, Monti G, Bólske G, Soderlund R, Ruiz M. European hares in Chile: a different lagomorph reservoir for Mycobacterium avium subsp. paratuberculosis? J Wild Dis 2011; 47 (3): 734-8. doi: 10.7589/0090-3558-47.3.734.

69.- Salgado M, Monti G, Sevilla I, Manning E. Association between cattle herd Mycobacterium avium subsp. paratuberculosis (MAP) infection and infection of a hare population. Trop Anim Health Prod 2014; 46 (7): 1313-6. doi: 10.1007/s11250-014-0637-y.

70.- Salgado M, Corti P, Verdugo C, Tomckowiack C, Moreira R, Durán K et al. Evidence of Mycobacterium avium subsp. paratuberculosis (MAP) infection in huemul deer (Hippocamelus bisulcus) in Patagonian fjords. Austral J Vet Sci 2017; 49 (2): 135-7. doi: $10.4067 / \mathrm{S} 0719-81322017000200135$.

71.- Povilitis A. El estado actual del huemul (Hippocamelus bisulcus) en Chile central. Gayana (Concep) 2002; 66 (1): 59-68. doi: $10.4067 / \mathrm{S} 0717-65382002000100008$. 
72.- Pradenas M, Navarrete-Talloni M J, Salgado M, Zamorano P, Paredes E. Paratuberculosis o tuberculosis aviar en ciervo rojo con diarrea crónica?. Arch Med Vet 2014; 46 (1): 45-52. doi: $10.4067 / \mathrm{S} 0301-732 \mathrm{X} 2014000100007$.

73.- Lobão-Tello E R, Herbach E P, NavarreteTalloni MJ. Paratuberculosis: new histopathological findings in red deer (Cervus elaphus) and fallow deer (Dama dama) in Chile. Pesqui Vet Bras 2017; 37 (7): 749-53. doi: 10.1590/S0100736X2017000700016.

74.- Naranjo V, Gortazar C, Vicente J, de la Fuente J. Evidence of the role of European wild boar as a reservoir of Mycobacterium tuberculosis complex. Vet Microbiol 2008; 127 (1-2): 1-9. doi: 10.1016/j.vetmic.2007.10.002.

75.- Skewes O, Jaksic F M. History of the introduction and present distribution of the european wild boar (Sus scrofa) in Chile. Mastozool Neotrop 2015; 22 (1): 113-24. http://www.scielo.org.ar/pdf/mznt/v22n1/ v22n1a12.pdf.

76.- Deem S L, Spelman L H, Yates R A, Montali R J. Canine distemper in terrestrial carnivores: a review. J Zoo Wild Med 2000; 31 (4): 441-51. doi: 10.1638/1042-7260(2000)031[0441:CDIT CA]2.0.CO;2.

77.- Thorne E T, Williams E S. Disease and endangered species: the black-footed ferret as a recent example. Conserv Biol 1988; 2: 66-74. doi: 10.1111/j.1523-1739.1988. tb00336.x.

78.- Acosta-Jamett G, Surot D, Cortés M, Marambio V, Valenzuela C, Vallverdu A, et al. Epidemiology of canine distemper and canine parvovirus in domestic dogs in urban and rural areas of the Araucanía region in Chile. Vet Microbiol 2015b; 178 (3): 260-4. doi: 10.1016/j.vetmic.2015.05.012.

79.- Acosta-Jamett G, Chalmers W S K, Cunningham A A, Cleaveland S, Handel I G. Urban domestic dog populations as a source of canine distemper virus for wild carnivores in the Coquimbo region of Chile. Vet Microbiol 2011; 152 (3): 247-57. doi: 10.1016/j. vetmic.2011.05.008.

80.- Rubio A V, Fredes F, Bonacic C. Serological and parasitological survey of free-ranging Culpeo Foxes (Lycalopex culpaeus) in the Mediterranean biodiversity hotspot of central Chile. J Anim Vet Adv 2013; 12 (18): 1445-9. doi: 10.3923/javaa.2013.1445.1449.

81.- González-Acuña D, Ortega-Vásquez R, Rivera-Ramírez P, Cabello-Cabalin J. Verdacht auf Staupe beim Graufuchs (Pseudalopex griseus) im mittleren Chile (Fallbericht). Z Jagdwiss 2003; 49 (4): 323-6. doi: 10.4067/ S0301-732X2012000100014..

82.- Jiménez J E, Briceño C, Alcaíno $H$, Vásquez P, Funk S, González-Acuña D. Coprologic survey of endoparasites from Darwin's fox (Pseudalopex fulvipes) in Chiloé,
Chile. Arch Med Vet 2012; 44 (1): 93-7. doi: 10.1007/BF02189641.

83.- Steinel A, Parrish C R, Bloom M E, Truyen U. Parvovirus infections in wild carnivores. J Wild Dis 2001; 37 (3): 594-607. doi: 10.7589/00903558-37.3.594.

84.- Berríos P. Antecedentes en Chile de enfermedades virales de los animales domésticos. II. Enfermedades de presentación cíclica y de alta seroprevalencia. Avances en Ciencias Veterinarias 2002; 17 (1-2): 1-12. doi: 10.5354/0719-5273.2010.9211.

85.- Mora M, Napolitano C, Ortega R, Poulin E, Pizarro-Lucero J. Feline immunodeficiency virus and feline leukemia virus infection in free-ranging guignas (Leopardus guigna) and sympatric domestic cats in human perturbed landscapes on Chiloé Island, Chile. J Wild Dis 2015; 51 (1): 199-208. doi: 10.7589/2014-04114.

86.- Silva-Rodríguez E A, Ortega-Solís G R, Jiménez J E. Human attitudes toward wild felids in a human-dominated landscape of southern Chile. Cat News 2007; 46: 19-21. https://chile.unt.edu/sites/chile. unt.edu/files/catalogue/pdf $/ 55 \% 20$

Silva-Rodr\%C3\%ADguez $\% 20$ etal $\% 20$ HumanAttitudesFelids\%202007\%20CatNews. pdf.

87.- Lee J S, Bevins S N, Serieys L E K, Vickers W, Logan K A, Aldredge M, et al. Evolution of puma lentivirus in bobcats (Lynx rufus) and mountain lions (Puma concolor) in North America. J Virol 2014; 88 (14): 7727-37. doi: 10.1128/JVI.00473-14.

88.- Pizarro-Lucero J, Celedón M O, Navarro C, Ortega R, González D. Identification of a pestivirus isolated from a free-ranging pudu (Pudu puda) in Chile. Vet Rec 2005; 157(10): 292-4. PMID: 16157573.

89.- Corti P, Saucedo C, Herrera P. Evidence of bovine viral diarrhea, but absence of infectious bovine rhinotracheitis and bovine brucellosis in the endangered huemul deer (Hippocamelus bisulcus) in Chilean Patagonia. J Wild Dis 2013; 49 (3): 744-6. doi: 10.7589/2012-04-105.

90.- Van Bressem M F, Reyes J C, Félix F, Echegaray M, Siciliano S, Di Beneditto A P, et al. A preliminary overview of skin and skeletal diseases and traumata in small cetaceans from South American waters. LAJAM Latin Amer J Aquatic Mammals 2007; 6 (1): 7-42. doi: 10.5597/lajam00108.

91.- Van Bressem M F, Van Waerebeek K, Aznar F J, Raga J A, Jepson P D, Duignan P, et al. Epidemiological pattern of tattoo skin disease: a potential general health indicator for cetaceans. Dis Aquat Organ 2009; 85 (3): 225 37. doi: $10.3354 /$ dao02080.

92.- Van Bressem M F, Van Waerebeek K, Fleming M, Barrett T. Serological evidence of morbillivirus infection in small cetaceans from the Southeast Pacific. Vet Microb 1998; 59: 89-98. PMID: 9549850.

93.- Van Bressem M F, Van Waerebeek K, Raga J A, Godfroid J, Brew S D. Serologic evidence of Brucella infection in odontocetes from the south Pacific and the Mediterranean. Vet Rec 2001; 148: 657-61. PMID: 11400986.

94.- Van Bressem M F, Duignan P J, Banyard A, Barbieri M, Colegrove K M, De Guise S et al. Cetacean morbillivirus: current knowledge and future directions. Viruses 2014; 6 (12): 5145 81. doi: $10.3390 / \mathrm{v} 6125145$.

95.- Guglielmone A A, Robbins R G, Apanaskevich D A, Petney T N, Estrada-Peña A, Hprak I, et al. The Argasidae, Ixodidae and Nuttalliellidae (Acari: Ixodida) of the world: a list of valid species names. Zootaxa 2010; 2528: 1-28. doi: 10.1007/978-94-017-3526-1 2.

96.- Abarca K, López J, Perret C, Guerrero J, Godoy P, Veloz A, et al. Anaplasma platys in dogs, Chile. Emerg Infect Dis 2007; 13 (9): 1392-5. doi: 10.3201/eid1309.070021.

97.- López J, Abarca K, Mundaca M A, Caballero C, Valiente-Echeverría F. Identificación molecular de Ehrlichia canis en un canino de la ciudad de Arica, Chile. Rev Chilena Infectol 2012; 29 (5): 527-30. doi: $10.4067 / \mathrm{S} 0716-10182012000600008$.

98.- Abarca K, López J, Acosta-Jamett G, Martínez-Valdebenito C. Identificación de Rickettsia andeanae en dos regiones de Chile. Rev Chilena Infectol 2013; 30 (4): 388-94. doi: $10.4067 /$ S0716- 10182013000400006 .

99.- Abarca K, López J, Acosta-Jamett G, Martínez-Valdebenito C. Rickettsia felis in Rhipicephalus sanguineus from two distant Chilean cities. Vector Borne Zoonotic Dis 2013b; 13 (8): 607-9. doi: 10.1089/ vbz.2012.1201

100.- Müller A, Monti G, Otth C, Sepúlveda P, Bittencourt P, Nachum-Biala Y, et al. "Candidatus Neoehrlichia chilensis" sp. nov.: Molecular detection and characterization of a novel Anaplasmataceae in wild rodents from Valdivia, southern Chile. Transbound Emerg Dis 2018; 65 (2): 357-62. doi: 10.1111/tbed.12815.

101.- Pérez G G, Torres J, Santos F S, Martino S, Velazquez E, Ramón G. Borrelia burgdorferi infection and cutaneous Lyme disease, México. Emerg Infect Dis 2007; 13 (10): 1556-8. doi: 10.3201/eid1310.060630.

102.- Ivanova L B, Tomova A, González-Acuña D, Murúa R, Moreno C X, Hernández C, et al. Borrelia chilensis, a new member of the Borrelia burgdorferi sensu lato complex that extends the range of this genospecies in the Southern Hemisphere. Env Microbiol 2014; 16 (4): 1069-80. doi: 10.1111/1462-2920.12310.

103.- Verdugo C, Jiménez O, Hernández C, Álvarez $\mathrm{P}$, Espinoza A, González-Acuña D. Infection with Borrelia chilensis in Ixodes stilesi ticks 
collected from Pudu puda deer. Ticks Tick Borne Dis 2017; 8 (5): 733-40. doi: 10.1016/j. ttbdis.2017.05.00.

104.- Bengis R G, Kock R A, Fischer J. Infectious animal diseases: the wildlife/livestock interface. Rev Sci Tech 2002; 21 (1): 53-65. PMID: 1197463.

105.- Rhyan J C, Spraker T R. Emergence of diseases from wildlife reservoirs. Vet Pathol 2010; 47 (1): 34-9. doi: $10.1177 / 0300985809354466$.

106.- Povilitis A. Characteristics and conservation of a fragmented population of huemul Hippocamelus bisulcus in central Chile. Biol Conserv 1998; 86 (1): 97-104. doi: 10.1016/ S0006-3207(97)00161-4

107.- Morales N, Aldridge D, Bahamonde A, Cerda J, Araya C, Muñoz R, et al. Corynebacterium pseudotuberculosis Infection in Patagonian Huemul (Hippocamelus bisulcus). J Wild Dis 2017; 53 (3): 621-4. doi: 10.7589/2016-09-213.

108.- Young J K, Olson K A, Reading R P, Amgalanbaatar S, Berger J. Is wildlife going to the dogs? Impacts of feral and free-roaming dogs on wildlife populations. BioScience 2011; 61 (2): 125-32. doi: 10.1525/ bio.2011.61.2.7.

109.- Mamaev L V, Denikina N N, Belikov S I, Volchkov V E, Visser I K G, et al. Characterisation of morbilliviruses isolated from Lake Baikal seals (Phoca sibirica). Vet Microbiol 1995; 44 (2-4): 251-9. doi: 10.1016/0378-1135(95)00018-6.

110.- Silva R F, Riedemann S. Seroprevalencia de leptospirosis canina en perros atendidos en clínicas veterinarias, mediante aglutinación microscópica y comparación con las técnicas de aislamiento e inmunofluorescencia indirecta. Arch Med Vet 2007; 39 (3): 269-74 doi: 10.4067/S0301- 732X2007000300011.

111.- Núñez F, Favi M, Urcelay V, Sepúlveda C,
Fabrega F. Rabia silvestre en murciélagos insectívoros en Chile. Bol Of Sanit Panam 1987; 103 (2): 140-5. http://iris.paho.org/ xmlui/bitstream/handle/123456789/18008/ v103n2p140.pdf? sequence $=1$.

112.- Favi M, Yung V, Pavletic C, Ramírez E, De Mattos C, De Mattos C A. Rol de los murciélagos insectívoros en la transmisión de la rabia en Chile. Arch Med Vet 1999; 31 (2): 157-65. doi: 10.4067/S0301732X1999000200002.

113.- Yung V, Favi M, Fernández J. Genetic and antigenic typing of rabies virus in Chile. Arch Virol 2002; 147 (11): 2197-205. doi: 10.1007/ s00705-002-0894-3.

114.- Cabello J, Esperon F, Napolitano C, Hidalgo E, Dávila J A, Millán J. Molecular identification of a novel gammaherpesvirus in the endangered Darwin's fox (Lycalopex fulvipes). J Gen Virol 2013; 94 (12): 2745-9. doi: 10.1099/vir.0.057851-0.

115.- Castelli M. Investigaciones sobre la existencia de leptospiras y leptospirosis en Chile. Bol Inst Bacteriol Chil 1959; 11: 5-31.

116.- Muñoz-Zanzi C, Mason M, Encina C, González M, Berg S. Household characteristics associated with Rodent presence and Leptospira infection in rural and urban communities from South Chile. Am J Trop Med Hyg 2014; 90 (3): 497-506. doi: 10.4269/ ajtmh.13-0334.

117.- Zamora J, Alonso O, Chahuan E. Isolement et caractérisation de Yersinia enterocolitica chez les rongeurs sauvages du Chili. Zentralbl Veterinarmed B 1979; 26 (5): 392-6. PMID: 532480.

118.- Cabello J, Altet L, Napolitano C, Sastre N, Hidalgo E, Dávila J A, et al. Survey of infectious agents in the endangered Darwin's fox (Lycalopex fulvipes): High prevalence and diversity of hemotrophic mycoplasmas. Vet Microbiol 2013; 167 (3): 448-54. doi: 10.1016/j.vetmic.2013.09.034.

119.- Sturm N, Abalos P, Fernández A, Rodríguez G, Oviedo P, Arroyo V, Retamal P. Salmonella enterica in pinnipeds, Chile. Emerg Infect Dis 2011; 17 (12): 2377-8. doi: 10.3201/ eid1712.111103.

120.- Toro M, Retamal P, Allard M, Brown EW, Evans P, Gonzalez-Escalona N. Draft genome sequences of 33 Salmonella enterica clinical and wildlife isolates from Chile. Genome Announc 2015; 3(2): e00054-15. doi: 10.1128/ genomeA.00054-15.

121.- Salinas P, Moraga R, Santander E, Sielfeld W. Presencia de cepas diarreogénicas de Escherichia coli y estudio de genes de virulencia en aislados desde fecas de dos poblaciones de lobo marino común, Otaria flavescens en el norte de Chile. Rev Biol Mar Oceanogr 2010; 45 (1): 153-8. doi: 10.4067/ S0718- 19572010000100016.

122.- González M, Villanueva M P, Debruyne L, Vandamme P, Fernández H. Campylobacter insulaenigrae: first isolation report from South American sea lion Otaria flavescens (Shaw, 1800). Braz J Microbiol 2011; 42 (1): 261-5. doi: 10.1590/S151783822011000100033.

123.- González-Fuentes M, Latif F, Fernández F, Villanueva M P, Ulloa J, Fernández H. Especies de la familia Enterobacteriaceae en heces de lobo marino común, Otaria flavescens establecido en el río Valdivia. Rev Biol Mar Oceanogr 2010; 45 (2): 331-4. doi: 10.4067/ S0718-19572010000200015.

124.- Mathieu X, Durán J C, Rivas R M. Estudio de la flora bacteriana normal de Chinchilla lanigera silvestre. Rev Latinoam Microbiol 1982; 24: 77-82. PMID: 7186674. 